\title{
Different pathways of the formation of highly oxidized multifunctional organic compounds (HOMs) from the gas-phase ozonolysis of $\beta$-caryophyllene
}

\author{
Stefanie Richters, Hartmut Herrmann, and Torsten Berndt \\ Leibniz Institute for Tropospheric Research, TROPOS, 04315 Leipzig, Germany \\ Correspondence to: Stefanie Richters (richters@tropos.de) \\ Received: 9 March 2016 - Published in Atmos. Chem. Phys. Discuss.: 14 March 2016 \\ Revised: 15 July 2016 - Accepted: 15 July 2016 - Published: 4 August 2016
}

\begin{abstract}
The gas-phase mechanism of the formation of highly oxidized multifunctional organic compounds (HOMs) from the ozonolysis of $\beta$-caryophyllene was investigated in a free-jet flow system at atmospheric pressure and a temperature of $295 \pm 2 \mathrm{~K}$. Reaction products, mainly highly oxidized $\mathrm{RO}_{2}$ radicals containing up to 14 oxygen atoms, were detected using chemical ionization - atmospheric pressure interface - time-of-flight mass spectrometry with nitrate and acetate ionization.

These highly oxidized $\mathrm{RO}_{2}$ radicals react with $\mathrm{NO}, \mathrm{NO}_{2}$, $\mathrm{HO}_{2}$ and other $\mathrm{RO}_{2}$ radicals under atmospheric conditions forming the first-generation HOM closed-shell products.

Mechanistic information on the formation of the highly oxidized $\mathrm{RO}_{2}$ radicals is based on results obtained with isotopically labelled ozone $\left({ }^{18} \mathrm{O}_{3}\right)$ in the ozonolysis reaction and from hydrogen/deuterium (H/D) exchange experiments of acidic $\mathrm{H}$ atoms in the products. The experimental findings indicate that HOM formation in this reaction system is considerably influenced by the presence of a double bond in the $\mathrm{RO}_{2}$ radicals primarily formed from the $\beta$ caryophyllene ozonolysis. Three different reaction types for HOM formation can be proposed, allowing for an explanation of the detected main products: (i) the simple autoxidation, corresponding to the repetitive reaction sequence of intramolecular $\mathrm{H}$-abstraction of a $\mathrm{RO}_{2}$ radical, $\mathrm{RO}_{2} \rightarrow \mathrm{QOOH}$, and subsequent $\mathrm{O}_{2}$ addition, next forming a peroxy radical, $\mathrm{QOOH}+\mathrm{O}_{2} \rightarrow \mathrm{R}^{\prime} \mathrm{O}_{2}$; (ii) an extended autoxidation mechanism additionally involving the internal reaction of a $\mathrm{RO}_{2}$ radical with a double bond forming most likely an endoperoxide and (iii) an extended autoxidation mechanism including $\mathrm{CO}_{2}$ elimination. The individual reaction steps of the reaction types (ii) and (iii) are uncertain at the moment. From
\end{abstract}

the product analysis it can be followed that the simple autoxidation mechanism accounts only for about one-third of the formed HOMs.

Time-dependent measurements showed that the HOM formation proceeds at a timescale of $3 \mathrm{~s}$ or less under the concentration regime applied here.

The new reaction pathways represent an extension of the mechanistic understanding of HOM formation via autoxidation in the atmosphere, as recently discovered from laboratory investigations on monoterpene ozonolysis.

\section{Introduction}

The emission of biogenic volatile organic compounds (BVOCs) from vegetation to the troposphere and their oxidation in the gas phase is the subject of intense research (Calvert et al., 2000; Guenther et al., 2012; Ziemann and Atkinson, 2012).

Sesquiterpenes (SQTs, $\mathrm{C}_{15} \mathrm{H}_{24}$ ) with an annual emission of 18-24 million metric tons of carbon (Messina et al., 2015; Sindelarova et al., 2014) contribute up to $3 \%$ of the annual global BVOC emission of 720-1150 million metric tons of carbon (Guenther et al., 1995, 2012; Lathière et al., 2005; Sindelarova et al., 2014). They are emitted by a large variety of plants and fungi and their emission pattern depends strongly on the region and the season (Ciccioli et al., 1999; Duhl et al., 2008; Geron and Arnts, 2010; Horváth et al., 2011; Jardine et al., 2011). Biotic stress can drastically increase SQT emissions (Mentel et al., 2013). $\beta$-Caryophyllene emissions were calculated to account for 
$25 \%$ of global SQT emissions (Guenther et al., 2012) and can contribute $70 \%$ to the regional BVOC emissions, e.g. in orange orchards (Ciccioli et al., 1999; Duhl et al., 2008). The oxidation products are expected to have a very low vapour pressure making them important for the process of secondary organic aerosol (SOA) formation (Jaoui et al., 2013; Zhao et al., 2016).

$\beta$-Caryophyllene is mainly oxidized by ozone under atmospheric conditions having a lifetime $\tau_{\left(\mathrm{O}_{3}\right)}=$ $2 \mathrm{~min}$ for an average ozone concentration of $\left[\mathrm{O}_{3}\right]=7 \times$ $10^{11}$ molecules $\mathrm{cm}^{-3}$ (Finlayson-Pitts and Pitts, 1986) and a rate coefficient $k_{(296 \mathrm{~K})}=1.1 \times 10^{-14} \mathrm{~cm}^{3}$ molecule ${ }^{-1} \mathrm{~s}^{-1}$ (Richters et al., 2015; Shu and Atkinson, 1994). Gas-phase product formation from the ozonolysis of $\beta$-caryophyllene was already studied in a series of laboratory investigations (Calogirou et al., 1997; Grosjean et al., 1993; Jaoui et al., 2003; Lee et al., 2006; Winterhalter et al., 2009) and by means of theoretical calculations (Nguyen et al., 2009). A large variety of carbonyl, epoxide and carboxyl compounds containing up to five oxygen atoms were experimentally observed using different detection techniques. The total carbon yield, comprising gas- and particle-phase products, accounts for up to $64 \%$ (Jaoui et al., 2003). A summary of available data in the literature is given by Winterhalter et al. (2009). DFT (density functional theory) quantum chemical calculations were conducted accompanying the experimental work by Winterhalter et al. (2009) with special attention to the first oxidation steps. The fraction of stabilized Criegee intermediates at atmospheric pressure was calculated to be $74 \%$, slightly higher than the experimental value of $60 \%$. Furthermore, the calculations support the proposed uni- and bimolecular reaction pathways of the Criegee intermediates as proposed from the experimental work. The main reaction product was stated to be the secondary ozonide with a yield of $64 \%$. The formation of acids should account for $8 \%$, dominated by the formation of caryophyllonic acid (Nguyen et al., 2009). This value is slightly lower than the overall gasand aerosol-phase yield of $13.5 \%$ for caryophyllonic acid measured by Jaoui et al. (2003).

Recently, Ehn et al. $(2012,2014)$ detected highly oxidized multifunctional organic compounds (HOMs) from the oxidation of $\alpha$-pinene in field and laboratory studies. These HOMs contain up to 12 oxygen atoms and are supposed to have a very low vapour pressure, which led to their classification as extremely low-volatility organic compounds (ELVOCs) and as important precursors for SOA formation (Ehn et al., 2014).

Other experimental work on HOM formation from the ozonolysis of monoterpenes (Jokinen et al., 2014; Mentel et al., 2015) and model substances, such as cyclohexene (Berndt et al., 2015b; Mentel et al., 2015; Rissanen et al., 2014), led to the development of an autoxidation mechanism based on $\mathrm{RO}_{2}$ radical chemistry. In this process, an $\mathrm{RO}_{2}$ radical internally abstracts an $\mathrm{H}$ atom, forming an alkyl radical with a hydroperoxide moiety $\left(\mathrm{RO}_{2} \rightarrow \mathrm{QOOH}\right)$. Subsequent oxygen addition forms the next $\mathrm{R}^{\prime} \mathrm{O}_{2}$ radical
$\left(\mathrm{QOOH}+\mathrm{O}_{2} \rightarrow \mathrm{R}^{\prime} \mathrm{O}_{2}\right)$ (Berndt et al., 2015b; Crounse et al., 2013; Ehn et al., 2014; Jokinen et al., 2014; Rissanen et al., 2014), which can repeat this reaction sequence. The overall process results in a repetitive oxygen insertion into the molecules on a timescale of seconds (Jokinen et al., 2014). The principle of autoxidation is well known from the liquid phase for more than 100 years (Berezin et al., 1996; Jazukowitsch, 1875) and was recently extended to atmospheric gas-phase reactions (Crounse et al., 2013).

For alkenes with multiple double bonds, such as $\beta$ caryophyllene, this mechanism can become more complex caused by the variety of possible reaction pathways of unsaturated $\mathrm{RO}_{2}$ radicals formed as the intermediates. A recent study from this laboratory showed that the HOM formation from the ozonolysis of $\alpha$-cedrene (a SQT that contains only a single double bond) was completely explainable by the autoxidation mechanism initiated by the ozone attack on the double bond (Richters et al., 2016). On the other hand, in the case of the analogous reaction of $\beta$-caryophyllene (containing two double bonds), the product spectrum was more complex and not fully in line with an autoxidation mechanism $\left(\mathrm{RO}_{2} \rightarrow \mathrm{QOOH}, \mathrm{QOOH}+\mathrm{O}_{2} \rightarrow \mathrm{R}^{\prime} \mathrm{O}_{2}\right)$. This fact points to additional reaction pathways for HOM generation most likely caused by the presence of a second double bond.

The scope of the present work is the mechanistic elucidation of possible new reaction pathways of HOM formation starting from the ozonolysis of $\beta$-caryophyllene. Experiments with heavy water $\left(\mathrm{D}_{2} \mathrm{O}\right)$ and isotopically labelled ozone $\left({ }^{18} \mathrm{O}_{3}\right)$ were conducted in order to obtain additional information on elementary reaction pathways needed to explain the observed products. This approach allowed for developing an extended mechanism for the HOM formation from the ozonolysis of $\beta$-caryophyllene.

\section{Experimentation}

The gas-phase ozonolysis of $\beta$-caryophyllene was investigated in a free-jet flow system at a temperature of $295 \pm 2 \mathrm{~K}$ and a pressure of 1 bar purified air. The experimental approach is described in detail in the literature (Berndt et al., 2015a, b; Richters et al., 2016) and only a brief summary will be given here.

Experiments in the free-jet flow system (outer tube length: $200 \mathrm{~cm}, 15 \mathrm{~cm}$ inner diameter, and a moveable inner tube: $9.5 \mathrm{~mm}$ outer diameter with a nozzle) were conducted under conditions of negligible wall loss of products and with a reaction time of 3.0-7.9 s (Berndt et al., 2015a). The inner flow of $5 \mathrm{~L} \mathrm{~min}^{-1}$ (STP, standard temperature and pressure), containing varying ozone concentrations, was injected through a nozzle to the outer airflow of $95 \mathrm{~L} \mathrm{~min}^{-1}$ (STP), which contained $\beta$-caryophyllene and $\mathrm{CH}_{3} \mathrm{COOH}$ if needed. The addition of $\mathrm{CH}_{3} \mathrm{COOH}$ was used to scavenge stabilized Criegee intermediates from the ozonolysis of $\beta$-caryophyllene (Beck et al., 2011; Neeb et al., 1996). Turbulent gas mixing down- 
stream of the nozzle rapidly generates a homogeneously mixed reactant gas.

Ozone was produced by passing air or ${ }^{18} \mathrm{O}_{2}$, premixed in $\mathrm{N}_{2}$, through an ozone generator (UVP OG-2) and was measured at the outflow of the reactor by a gas monitor (Thermo Environmental Instruments 49C). All gas flows were set by calibrated gas flow controllers (MKS 1259/1179). $\beta$ Caryophyllene was stored in flasks maintained at $278 \mathrm{~K}$, carried along with $38-48 \mathrm{~mL} \mathrm{~min}^{-1}$ (STP) nitrogen, and diluted with the air stream just before entering the flow system. Gas chromatography with a flame - ionization detector (GC-FID; Agilent 6890) as well as proton transfer reaction - mass spectrometry (PTR-MS; HS PTR-QMS 500, Ionicon) served as the analytical techniques for $\beta$-caryophyllene detection.

The absolute $\beta$-caryophyllene concentrations were determined using the "effective carbon-number approach" from GC-FID analysis using a series of reference substances with known concentrations (Scanlon and Willis, 1985). The reference substances were $\alpha$-pinene, $\beta$-pinene and limonene. The ratio of the effective carbon numbers (equal to the signal ratio for identical sample concentrations) of $\beta$-caryophyllene with respect to these monoterpenes is 1.5 (Helmig et al., 2003; Scanlon and Willis, 1985). Before each measurement series, the concentration was determined using GC-FID analysis measuring the $\beta$-caryophyllene signal as well as the signals of the reference substances with known concentrations simultaneously. The $\beta$-caryophyllene concentration in the flow system was continuously monitored throughout the experiments by PTR-MS measurements following the ion traces at 205, 147 and $137 \mathrm{amu}$.

The $\beta$-caryophyllene conversion was varied by changing the initial ozone concentration for otherwise constant reaction conditions. The needed gas mixture of $\mathrm{CH}_{3} \mathrm{COOH}$ was prepared in a gas-mixing unit.

The reactant gases used had the following purities: $\beta$-caryophyllene (98.5\%; Aldrich), $\mathrm{CH}_{3} \mathrm{COOH}$ (Aldrich; $99.5 \%$ ), $\mathrm{N}_{2}$ (Air Products; $99.9992 \%$ ), ${ }^{18} \mathrm{O}_{2}$ (euriso-top, isotopic enrichment $96 \%$ ). Air was taken from a PSA (pressure swing adsorption) unit with further purification by activated charcoal and $4 \AA$ molecular sieve. If needed, humidified air was produced by passing a part of the airflow through water saturators filled with $\mathrm{D}_{2} \mathrm{O}$ (Aldrich, 99.9 atom \%).

Reaction products were detected and quantified by means of chemical ionization - atmospheric pressure interface time-of-flight (CI-APi-TOF) mass spectrometry (Airmodus, Tofwerk) using nitrate ions and acetate ions for chemical ionization. The mass spectrometer settings (applied voltages and flow rates) as well as the approach applied for the determination of HOM concentrations are equal to those described in detail by Berndt et al. (2015b). All stated concentrations represent lower limits (Berndt et al., 2015b). The calculation of HOM concentrations and information about detection limitations and the mass axis calibration are given in the Supplement.
The initial concentrations were (unit: molecules $\mathrm{cm}^{-3}$ ) $[\beta$ caryophyllene $]=(8.3-8.6) \times 10^{10} ;\left[\mathrm{O}_{3}\right]=(4.7-102) \times 10^{10}$ and $\left[\mathrm{CH}_{3} \mathrm{COOH}\right]=(0-1.4) \times 10^{14}$.

\section{Results and discussion}

A series of different experiments was conducted in order to investigate the product formation from the ozonolysis of $\beta$-caryophyllene in more detail. In Sect. 3.1, three different groups of products are proposed as a result of the identified signals from mass spectra recorded from runs with nitrate and acetate ionization. The experimental findings utilized for the signal assignment to the different product groups are described in the following sections. Section 3.2 discusses results from experiments with normal $\left({ }^{16} \mathrm{O}_{3}\right)$ or isotopically labelled ozone $\left({ }^{18} \mathrm{O}_{3}\right)$ which allows for distinguishing between the origin of the $\mathrm{O}$-atoms in the reaction products arising either from attacking ozone or from air $\mathrm{O}_{2}$. Experiments with $\mathrm{D}_{2} \mathrm{O}$ added to the carrier gas provide information about the total number of acidic $\mathrm{H}$ atoms in each reaction product, being equal to the number of $\mathrm{OH}$ and $\mathrm{OOH}$ groups; see Sect. 3.3.

\subsection{Three groups of highly oxidized products}

Figure 1 shows two product mass spectra from $\beta$ caryophyllene ozonolysis in the mass-to-charge range 345$505 \mathrm{Th}$, which were recorded (a) with acetate ionization and (b) with nitrate ionization. The products appear as adducts with the reagent ion (Ehn et al., 2014). Here, a signal of the same product shows a shift by three nominal mass units comparing acetate ion adducts ( +59 nominal mass units) with nitrate ion adducts (+62 nominal mass units). Mainly $\mathrm{RO}_{2}$ radicals were detected as reaction products because the $\mathrm{RO}_{2}$ radical concentrations did not exceed $9 \times 10^{6}$ molecules $\mathrm{cm}^{-3}$ and bimolecular reactions of the formed $\mathrm{RO}_{2}$ radicals were less efficient for a reaction time of $3.0-7.9 \mathrm{~s}$ in these experiments. Therefore, the discussion is mainly focused on $\mathrm{RO}_{2}$ radicals.

The observed product signals were classified in three product groups. The position of the dominant signals in each product group differs by 32 nominal mass units each due to the stepwise insertion of oxygen molecules.

Signals of the first group, the so-called simple autoxidation group, "simple AutOx.", appear at the same positions in the mass spectrum as observed from the HOM formation of $\alpha$-cedrene ozonolysis (an SQT with only one double bond, but with the same chemical formula $\mathrm{C}_{15} \mathrm{H}_{24}$ like $\beta$ caryophyllene) (Richters et al., 2016). The $\mathrm{RO}_{2}$ radicals from this group were summarized by the general formula $\mathrm{O}, \mathrm{O}$ $\mathrm{C}_{15} \mathrm{H}_{23-x}(\mathrm{OOH})_{x} \mathrm{O}_{2}$ with $x=1-5$ (Jokinen et al., 2014; Richters et al., 2016). Here, $x$ stands for the number of hydroperoxide moieties in the molecule, the two oxygen atoms $\mathrm{O}, \mathrm{O}-$ arise from the initial ozone attack and the final $\mathrm{O}_{2}$ 


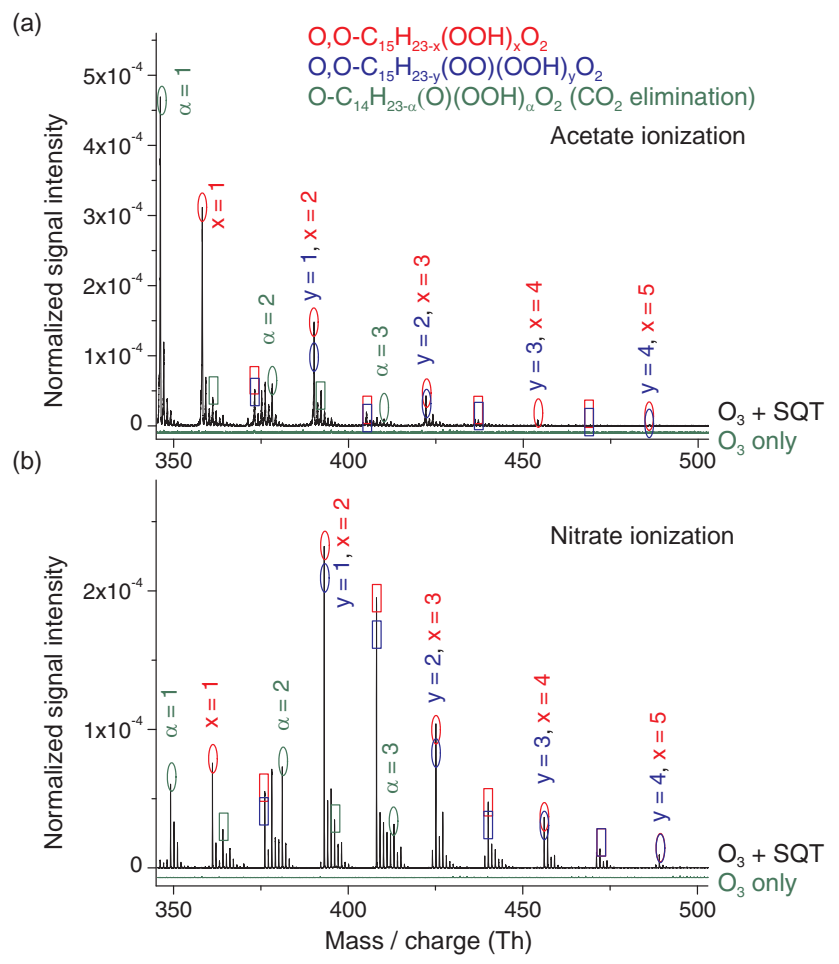

Figure 1. Highly oxidized $\mathrm{RO}_{2}$ radicals of the three product groups, simple AutOx., $\mathrm{O}, \mathrm{O}-\mathrm{C}_{15} \mathrm{H}_{23-x}(\mathrm{OOH})_{x} \mathrm{O}_{2}$, with $x=1-5$ (in red), ext. AutOx., O,O- $\mathrm{C}_{15} \mathrm{H}_{23-y}(\mathrm{OO})(\mathrm{OOH})_{y} \mathrm{O}_{2}$ with $y=1-$ 4 (in blue) and ext. AutOx. $-\mathrm{CO}_{2}, \mathrm{O}-\mathrm{C}_{14} \mathrm{H}_{23-\alpha}(\mathrm{O})(\mathrm{OOH})_{\alpha} \mathrm{O}_{2}$ with $\alpha=1-3$ (in green), and corresponding closed-shell products (rectangular lines) appearing at -17 nominal mass units regarding the corresponding $\mathrm{RO}_{2}$ radical. The products were detected by means of (a) acetate ionization and (b) nitrate ionization. The same molecule gives a signal shifted by three nominal mass units, comparing the acetate ion adducts ( +59 nominal mass units) with the nitrate ion adducts (+62 nominal mass units). The mass spectra were normalized by their reagent ion counts. Signals from the simple AutOx. group and the ext. AutOx. group were detected at the same mass-to-charge ratio. The green spectrum lines $\left(\mathrm{O}_{3}\right.$ only) shows the background experiments in which only ozone (no SQT) was present. The data of (b) were taken from Richters et al. (2016). [ $\beta$-caryophyllene $]=8.6 \times 10^{10}$ (acetate ionization), $[\beta$-caryophyllene $]=8.3 \times 10^{10}$ (nitrate ionization), $\left[\mathrm{O}_{3}\right]=1.02 \times$ $10^{12}$ molecules $\mathrm{cm}^{-3}$, reaction time is $7.9 \mathrm{~s}$.

stands for the $\mathrm{RO}_{2}$ radical functional group (Jokinen et al., 2014). The carbon skeleton of 15 carbon atoms is retained and up to 14 oxygen atoms are inserted into the products. The number of oxygen atoms arising from the initial ozone attack was confirmed in experiments with isotopically labelled ozone $\left({ }^{18} \mathrm{O}_{3}\right)$ (Fig. 2).

The second product group, the extended autoxidation group "ext. AutOx.", comprises the signals of $\mathrm{RO}_{2}$ radicals with the general formula $\mathrm{O}, \mathrm{O}-\mathrm{C}_{15} \mathrm{H}_{23-y}(\mathrm{OO})(\mathrm{OOH})_{y} \mathrm{O}_{2}$ with $y=1-4$. Here, $(\mathrm{OO})$ stands - most likely - for an endoperoxide group. Reactions leading to this insertion step

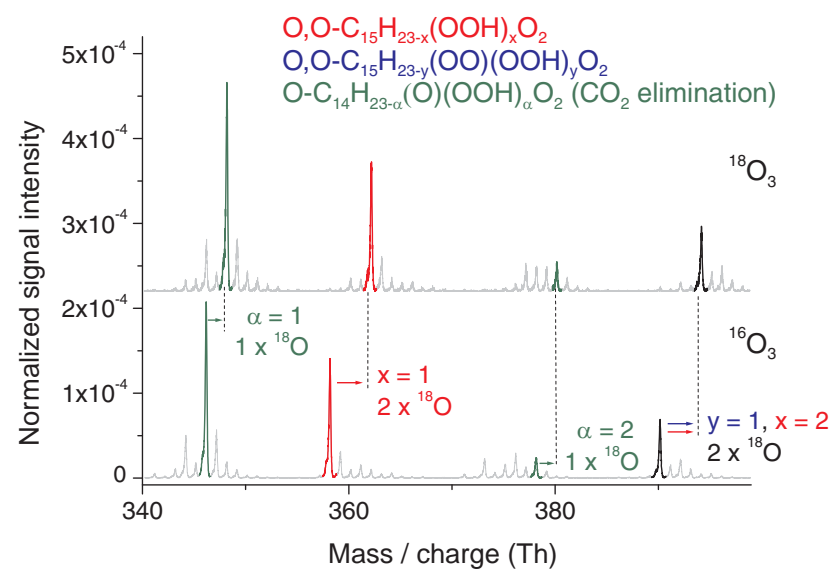

Figure 2. Ozonolysis of $\beta$-caryophyllene using ${ }^{16} \mathrm{O}_{3}$ (lower part) and ${ }^{18} \mathrm{O}_{3}$ (upper part) and applying acetate ionization in the analysis. Highly oxidized $\mathrm{RO}_{2}$ radicals of the three product groups, simple AutOx., O,O- $\mathrm{C}_{15} \mathrm{H}_{23-x}(\mathrm{OOH})_{x} \mathrm{O}_{2}$, with $x=1$ and 2 (in red), ext. AutOx., O,O- $\mathrm{C}_{15} \mathrm{H}_{23-y}(\mathrm{OO})(\mathrm{OOH})_{y} \mathrm{O}_{2}$ with $y=1$ (black signal with blue label) and ext. AutOx. $-\mathrm{CO}_{2}, \mathrm{O}-$ $\mathrm{C}_{14} \mathrm{H}_{23-\alpha}(\mathrm{O})(\mathrm{OOH})_{\alpha} \mathrm{O}_{2}$ with $\alpha=1$ and 2 (in green) were detected. The black-coloured signals at nominal $390 \mathrm{Th}\left({ }^{16} \mathrm{O}_{3}\right)$ and nominal $394 \mathrm{Th}\left({ }^{18} \mathrm{O}_{3}\right)$ stand for the sum of the signal from the simple AutOx. $\mathrm{RO}_{2}$ radical $\mathrm{O}, \mathrm{O}-\mathrm{C}_{15} \mathrm{H}_{23-x}(\mathrm{OOH})_{x} \mathrm{O}_{2}$ with $x=2$ and from the ext. AutOx. $\mathrm{RO}_{2}$ radical $\mathrm{O}, \mathrm{O}-\mathrm{C}_{15} \mathrm{H}_{23-y}(\mathrm{OO})(\mathrm{OOH})_{y} \mathrm{O}_{2}$ with $y=1$. Only the arrows and inscriptions $(y=1 ; x=2)$ indicate the colours of the product groups. When exchanging ${ }^{16} \mathrm{O}_{3}$ by ${ }^{18} \mathrm{O}_{3}$, the signals were shifted by two nominal mass units for each oxygen atom arising from the initial ozone attack. $[\beta$ caryophyllene $]=8.6 \times 10^{10},\left[\mathrm{O}_{3}\right]=8.8 \times 10^{11}$ molecules $\mathrm{cm}^{-3}$, reaction time is $7.9 \mathrm{~s}$.

are discussed in the reaction mechanisms in Sect. 3.4. $\mathrm{RO}_{2}$ radicals from the simple AutOx. group with $\mathrm{O}, \mathrm{O}-$ $\mathrm{C}_{15} \mathrm{H}_{23-x}(\mathrm{OOH})_{x} \mathrm{O}_{2}$ have the same chemical composition, and consequently the same position in the mass spectrum like the $\mathrm{RO}_{2}$ radicals from the ext. AutOx. group. A distinction is possible, measuring the number of acidic $\mathrm{H}$ atoms in the molecules (equal to the number of $\mathrm{OOH}$ groups) and applying hydrogen/deuterium (H/D) exchange experiments with heavy water (Figs. 3, 4) (Rissanen et al., 2014). Products of the ext. AutOx. group contain one less acidic $\mathrm{H}$ atom than the corresponding product from simple AutOx. with the same composition, for instance for $\mathrm{C}_{15} \mathrm{H}_{23} \mathrm{O}_{8}: \mathrm{O}, \mathrm{O}-\mathrm{C}_{15} \mathrm{H}_{23-y}(\mathrm{OO})(\mathrm{OOH})_{y} \mathrm{O}_{2}$ with $y=1$ and $\mathrm{O}, \mathrm{O}-\mathrm{C}_{15} \mathrm{H}_{23-x}(\mathrm{OOH})_{x} \mathrm{O}_{2}$ with $x=2$. H/D exchange experiments were successfully conducted in order to elucidate the number of $\mathrm{OOH}$ groups in the highly oxidized reaction product from the ozonolysis of cyclohexene, which represents a model compound for cyclic monoterpenes (Berndt et al., 2015b; Rissanen et al., 2014). In the case of cyclohexene ozonolysis, the formation of HOMs strictly followed the simple autoxidation mechanism, and the results of H/D exchange experiments confirmed the expected number of hydroperoxide moieties in the products. 


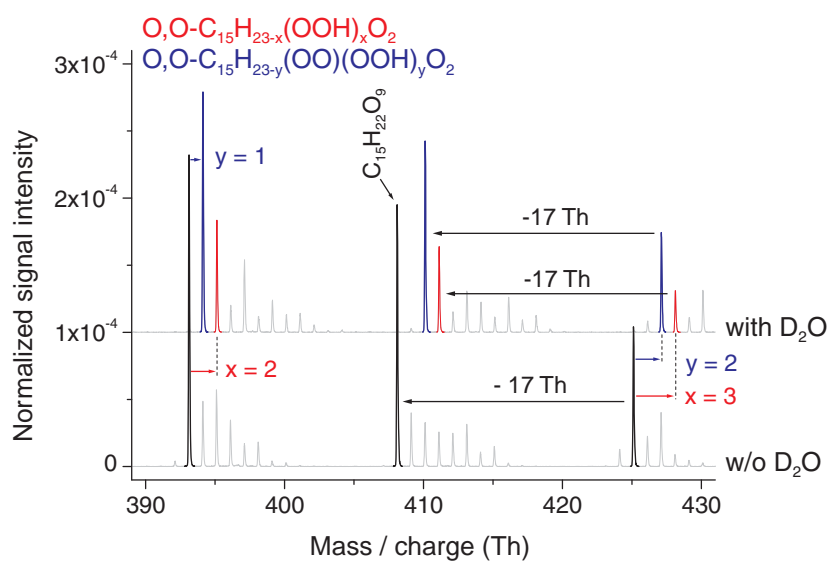

Figure 3. Ozonolysis of $\beta$-caryophyllene in the absence (lower part) and presence (upper part) of $\mathrm{D}_{2} \mathrm{O}$ applying nitrate ionization in the analysis. Signals highlighted in black stand for the sum of signals in the absence of $\mathrm{D}_{2} \mathrm{O}$ from highly oxidized $\mathrm{RO}_{2}$ radicals of the product groups simple AutOx., O,O- $\mathrm{C}_{15} \mathrm{H}_{23-x}(\mathrm{OOH})_{x} \mathrm{O}_{2}$ with $x=2$ and 3 , and ext. AutOx., O,O- $\mathrm{C}_{15} \mathrm{H}_{23-y}(\mathrm{OO})(\mathrm{OOH})_{y} \mathrm{O}_{2}$, with $y=1$ and 2 , and the corresponding closed-shell product $\mathrm{C}_{15} \mathrm{H}_{22} \mathrm{O}_{9}$ of the $\mathrm{RO}_{2}$ radicals for $x=3$ or $y=2$. The addition of $\mathrm{D}_{2} \mathrm{O}$ leads to an $\mathrm{H} / \mathrm{D}$ exchange of all acidic $\mathrm{H}$ atoms present in the molecule. Accordingly, signals from the two product groups are separated by the number of acidic $\mathrm{H}$ atoms and the split-up signals are highlighted in red for the simple AutOx. group and in blue for the ext. AutOx. group. [ $\beta$-caryophyllene] $=8.3 \times 10^{10}$, $\left[\mathrm{O}_{3}\right]=1.02 \times 10^{12}$ molecules $\mathrm{cm}^{-3}$, reaction time is $7.9 \mathrm{~s}$.

The third product group (extended autoxidation with $\mathrm{CO}_{2}$ elimination) named "ext. AutOx. $-\mathrm{CO}_{2}$ ", includes the signals of HOMs with a $\mathrm{C}_{14}$ skeleton formed by $\mathrm{CO}_{2}$ elimination in the course of their formation. Based on experiments with isotopically labelled ozone $\left({ }^{18} \mathrm{O}_{3}\right)$ (Fig. 2) and heavy water (Fig. 5), highly oxidized $\mathrm{RO}_{2}$ radicals of this product group were assigned to the general formula $\mathrm{O}-$ $\mathrm{C}_{14} \mathrm{H}_{23-\alpha}(\mathrm{O})(\mathrm{OOH})_{\alpha} \mathrm{O}_{2}$ with $\alpha=1-3$. Here, only one oxygen atom from the ozone attack, O-, is retained in the HOM. An additional oxygen atom, $(\mathrm{O})$, is inserted into the molecule arising from air $\mathrm{O}_{2}$. It is assumed that this $(\mathrm{O})$ exists in an epoxide ring. A possible reaction sequence leading to epoxide formation is discussed in Sect. 3.4.

Closed-shell products in all three product groups were detected at -17 nominal mass units compared with the position of the respective $\mathrm{RO}_{2}$ radical in the mass spectrum. The formation of closed-shell products as a result of consecutive, uni- or bimolecular reactions of the $\mathrm{RO}_{2}$ radicals can be explained by a formal loss of one oxygen and one hydrogen atom from the $\mathrm{RO}_{2}$ radical; see proposed reaction pathways as given by Jokinen et al. (2014).

The same reaction products $\left(\mathrm{RO}_{2}\right.$ radicals and closed-shell products) were detected by means of both ionization methods and all signal assignments were supported by the exact massto-charge ratio of the signals (resolving power at $393 \mathrm{Th}$ : $4100 \mathrm{Th} / \mathrm{Th}$ ). The detected signal intensity (normalized by

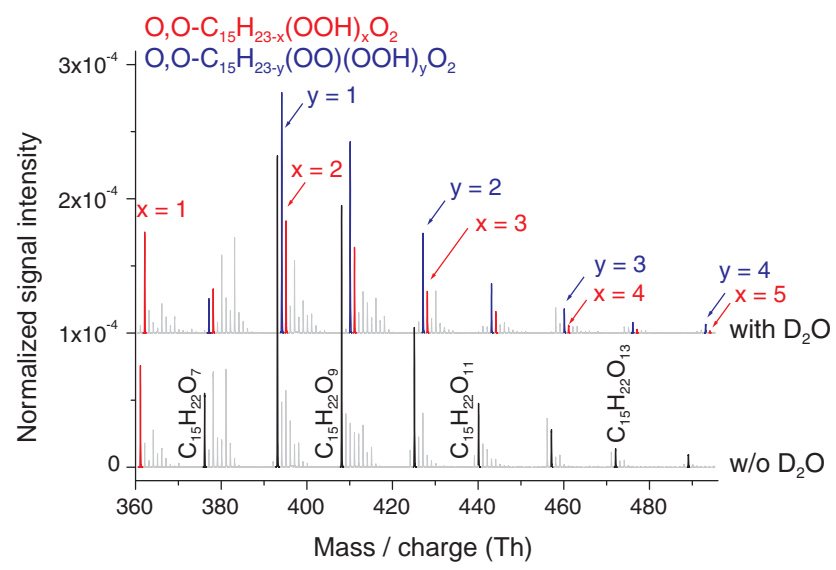

Figure 4. Ozonolysis of $\beta$-caryophyllene, in the absence (lower part) and presence (upper part) of $\mathrm{D}_{2} \mathrm{O}$ applying nitrate ionization in the analysis. Signals highlighted in black stand for the sum of signals in the absence of $\mathrm{D}_{2} \mathrm{O}$ from highly oxidized $\mathrm{RO}_{2}$ radicals of the product groups simple AutOx., O,O- $\mathrm{C}_{15} \mathrm{H}_{23-x}(\mathrm{OOH})_{x} \mathrm{O}_{2}$ with $x=2-5$, and ext. AutOx., O,O- $\mathrm{C}_{15} \mathrm{H}_{23-y}(\mathrm{OO})(\mathrm{OOH})_{y} \mathrm{O}_{2}$, with $y=1-4$, and the corresponding closed-shell product $\mathrm{C}_{15} \mathrm{H}_{22} \mathrm{O}_{7}$, $\mathrm{C}_{15} \mathrm{H}_{22} \mathrm{O}_{9}, \mathrm{C}_{15} \mathrm{H}_{22} \mathrm{O}_{11}, \mathrm{C}_{15} \mathrm{H}_{22} \mathrm{O}_{15}$. The addition of $\mathrm{D}_{2} \mathrm{O}$ leads to an $\mathrm{H} / \mathrm{D}$ exchange of all acidic $\mathrm{H}$ atoms present in the molecule. Accordingly, signals from the two product groups are separated by their number of acidic $\mathrm{H}$ atoms and the split-up signals are highlighted in red for the simple AutOx. group and in blue for the ext. AutOx. group. The signal at nominal $361 \mathrm{Th}$ can be completely assigned to the $\mathrm{RO}_{2}$ radical $\mathrm{O}, \mathrm{O}-\mathrm{C}_{15} \mathrm{H}_{23-x}(\mathrm{OOH})_{x} \mathrm{O}_{2}$ with $x=1$ and is highlighted in red. [ $\beta$-caryophyllene] $=8.3 \times$ $10^{10},\left[\mathrm{O}_{3}\right]=1.02 \times 10^{12}$ molecules $\mathrm{cm}^{-3}$, reaction time is $7.9 \mathrm{~s}$.

the reagent ion intensity) of the same HOM measured by both ionization techniques is not necessarily identical and is caused by possible differences of the cluster ion stability (Berndt et al., 2015b; Hyttinen et al., 2015). As a result of our analysis, acetate ionization is more sensitive, especially for the detection of HOMs that contain only one hydroperoxide moiety, $\mathrm{O}, \mathrm{O}-\mathrm{C}_{15} \mathrm{H}_{23-x}(\mathrm{OOH})_{x} \mathrm{O}_{2}$ with $x=1$ and $\mathrm{O}-$ $\mathrm{C}_{14} \mathrm{H}_{23-\alpha}(\mathrm{O})(\mathrm{OOH})_{\alpha} \mathrm{O}_{2}$ with $\alpha=1$. A similar observation has already been carried out for reaction products from the ozonolysis of cyclohexene (Berndt et al., 2015b). The signals of the HOMs with only one hydroperoxide moiety dominate the spectrum recorded with acetate ionization (Fig. 1a) but are of minor importance in the case of nitrate ionization (Fig. 1b). Table 1 summarizes the nominal mass-to-charge ratios of the detected signals and their assignments.

The analysis of the signal intensities points to an important role of reaction products from the ext. AutOx. and ext. AutOx. $-\mathrm{CO}_{2}$ groups for the total HOM formation from the ozonolysis of $\beta$-caryophyllene. The relative contribution of reaction products from the ext. AutOx. group to the estimated total molar HOM yield, investigated in the presence of $\mathrm{D}_{2} \mathrm{O}$ using nitrate ionization, was determined to be $49 \%$. The simple AutOx. group contribute $29 \%$ and the ext. AutOx. $-\mathrm{CO}_{2}$ with $22 \%$ to the estimated total molar HOM yield. 
Table 1. Highly oxidized reaction products from the ozonolysis of $\beta$-caryophyllene detected as nitrate ion adducts and acetate ion adducts using CI-APi-TOF mass spectrometry. Products were categorized into three product groups, i.e. simple AutOx., ext. AutOx. and ext. AutOx. $\mathrm{CO}_{2}$. Signals from the simple AutOx. and ext. AutOx. groups were detected at the same mass-to-charge ratio. The percentages indicate the contribution of a signal to the different product groups, simple AutOx. and ext. AutOx., as elucidated by H/D exchange experiments using nitrate ionization.

\begin{tabular}{|c|c|c|c|c|c|}
\hline \multicolumn{2}{|c|}{$\begin{array}{l}\text { Nominal mass-to- } \\
\text { charge ratio }\end{array}$} & \multirow[t]{2}{*}{$\begin{array}{l}\text { Molecular } \\
\text { formula }\end{array}$} & \multirow{2}{*}{$\begin{array}{l}\text { Product group } \\
\text { (contribution to the } \\
\text { total signal) }(\%)\end{array}$} & \multirow[t]{2}{*}{$\mathrm{RO}_{2}$ radical } & \multirow[t]{2}{*}{ Closed-shell product } \\
\hline $\begin{array}{l}\text { Nitrate ion } \\
\text { adducts }\end{array}$ & $\begin{array}{l}\text { Acetate ion } \\
\text { adducts }\end{array}$ & & & & \\
\hline 349 & 346 & $\mathrm{C}_{14} \mathrm{H}_{23} \mathrm{O}_{6}$ & ext. AutOx. $-\mathrm{CO}_{2}$ & $\mathrm{O}-\mathrm{C}_{14} \mathrm{H}_{22}(\mathrm{O})(\mathrm{OOH}) \mathrm{O}_{2}$ & \\
\hline 361 & 358 & $\mathrm{C}_{15} \mathrm{H}_{23} \mathrm{O}_{6}$ & simple AutOx. & $\mathrm{O}, \mathrm{O}-\mathrm{C}_{15} \mathrm{H}_{22}(\mathrm{OOH}) \mathrm{O}_{2}$ & \\
\hline 364 & 361 & $\mathrm{C}_{14} \mathrm{H}_{22} \mathrm{O}_{7}$ & ext. AutOx. $-\mathrm{CO}_{2}$ & & $\mathrm{O}-\mathrm{C}_{14} \mathrm{H}_{20} \mathrm{O}(\mathrm{O})(\mathrm{OOH})_{2}$ \\
\hline 376 & 373 & $\begin{array}{l}\mathrm{C}_{15} \mathrm{H}_{22} \mathrm{O}_{7} \\
\mathrm{C}_{15} \mathrm{H}_{22} \mathrm{O}_{7}\end{array}$ & $\begin{array}{ll}\text { simple AutOx. } & (56 \%) \\
\text { ext. AutOx. } & (44 \%)\end{array}$ & & $\begin{array}{l}\mathrm{O}, \mathrm{O}-\mathrm{C}_{15} \mathrm{H}_{20} \mathrm{O}(\mathrm{OOH})_{2} \\
\mathrm{O}, \mathrm{O}-\mathrm{C}_{15} \mathrm{H}_{21} \mathrm{O}(\mathrm{OO})(\mathrm{OOH})\end{array}$ \\
\hline 381 & 378 & $\mathrm{C}_{14} \mathrm{H}_{23} \mathrm{O}_{8}$ & ext. AutOx. $-\mathrm{CO}_{2}$ & $\mathrm{O}-\mathrm{C}_{14} \mathrm{H}_{21}(\mathrm{O})(\mathrm{OOH})_{2} \mathrm{O}_{2}$ & \\
\hline 393 & 390 & $\mathrm{C}_{15} \mathrm{H}_{23} \mathrm{O}_{8}$ & $\begin{array}{ll}\text { simple AutOx. } & (31 \%) \\
\text { ext. AutOx. } & (69 \%)\end{array}$ & $\begin{array}{l}\mathrm{O}, \mathrm{O}-\mathrm{C}_{15} \mathrm{H}_{21}(\mathrm{OOH})_{2} \mathrm{O}_{2} \\
\mathrm{O}, \mathrm{O}-\mathrm{C}_{15} \mathrm{H}_{22}(\mathrm{OO})(\mathrm{OOH}) \mathrm{O}_{2}\end{array}$ & \\
\hline 396 & 393 & $\mathrm{C}_{14} \mathrm{H}_{22} \mathrm{O}_{9}$ & ext. AutOx. $-\mathrm{CO}_{2}$ & & $\mathrm{O}-\mathrm{C}_{14} \mathrm{H}_{19} \mathrm{O}(\mathrm{O})(\mathrm{OOH})_{3}$ \\
\hline 408 & 405 & $\begin{array}{l}\mathrm{C}_{15} \mathrm{H}_{22} \mathrm{O}_{9} \\
\mathrm{C}_{15} \mathrm{H}_{22} \mathrm{O}_{9}\end{array}$ & $\begin{array}{ll}\text { simple AutOx. } & (30 \%) \\
\text { ext. AutOx. } & (70 \%)\end{array}$ & & $\begin{array}{l}\mathrm{O}, \mathrm{O}-\mathrm{C}_{15} \mathrm{H}_{19} \mathrm{O}(\mathrm{OOH})_{3} \\
\mathrm{O}, \mathrm{O}-\mathrm{C}_{15} \mathrm{H}_{20} \mathrm{O}(\mathrm{OO})(\mathrm{OOH})_{2}\end{array}$ \\
\hline 413 & 410 & $\mathrm{C}_{14} \mathrm{H}_{23} \mathrm{O}_{10}$ & ext. AutOx. $-\mathrm{CO}_{2}$ & $\mathrm{O}-\mathrm{C}_{14} \mathrm{H}_{20}(\mathrm{O})(\mathrm{OOH})_{3} \mathrm{O}_{2}$ & \\
\hline 425 & 422 & $\begin{array}{l}\mathrm{C}_{15} \mathrm{H}_{23} \mathrm{O}_{10} \\
\mathrm{C}_{15} \mathrm{H}_{22} \mathrm{O}_{9}\end{array}$ & $\begin{array}{ll}\text { simple AutOx. } & (29 \%) \\
\text { ext. AutOx. } & (71 \%)\end{array}$ & $\begin{array}{l}\mathrm{O}, \mathrm{O}-\mathrm{C}_{15} \mathrm{H}_{20}(\mathrm{OOH})_{3} \mathrm{O}_{2} \\
\mathrm{O}, \mathrm{O}-\mathrm{C}_{15} \mathrm{H}_{21}(\mathrm{OO})(\mathrm{OOH})_{2} \mathrm{O}_{2}\end{array}$ & \\
\hline 440 & 437 & $\begin{array}{l}\mathrm{C}_{15} \mathrm{H}_{22} \mathrm{O}_{11} \\
\mathrm{C}_{15} \mathrm{H}_{22} \mathrm{O}_{11}\end{array}$ & $\begin{array}{ll}\text { simple AutOx. } & (29 \%) \\
\text { ext. AutOx. } & (71 \%)\end{array}$ & & $\begin{array}{l}\mathrm{O}, \mathrm{O}-\mathrm{C}_{15} \mathrm{H}_{18} \mathrm{O}(\mathrm{OOH})_{4} \\
\mathrm{O}, \mathrm{O}-\mathrm{C}_{15} \mathrm{H}_{19} \mathrm{O}(\mathrm{OO})(\mathrm{OOH})_{3}\end{array}$ \\
\hline 457 & 454 & $\begin{array}{l}\mathrm{C}_{15} \mathrm{H}_{23} \mathrm{O}_{12} \\
\mathrm{C}_{15} \mathrm{H}_{23} \mathrm{O}_{12}\end{array}$ & $\begin{array}{ll}\text { simple AutOx. } & (25 \%) \\
\text { ext. AutOx. } & (75 \%)\end{array}$ & $\begin{array}{l}\mathrm{O}, \mathrm{O}-\mathrm{C}_{15} \mathrm{H}_{19}(\mathrm{OOH})_{4} \mathrm{O}_{2} \\
\mathrm{O}, \mathrm{O}-\mathrm{C}_{15} \mathrm{H}_{20}(\mathrm{OO})(\mathrm{OOH})_{3} \mathrm{O}_{2}\end{array}$ & \\
\hline 472 & 469 & $\begin{array}{l}\mathrm{C}_{15} \mathrm{H}_{22} \mathrm{O}_{13} \\
\mathrm{C}_{15} \mathrm{H}_{22} \mathrm{O}_{13}\end{array}$ & $\begin{array}{ll}\text { simple AutOx. } & (22 \%) \\
\text { ext. AutOx. } & (78 \%)\end{array}$ & & $\begin{array}{l}\mathrm{O}, \mathrm{O}-\mathrm{C}_{15} \mathrm{H}_{17} \mathrm{O}(\mathrm{OOH})_{5} \\
\mathrm{O}, \mathrm{O}-\mathrm{C}_{15} \mathrm{H}_{18} \mathrm{O}(\mathrm{OO})(\mathrm{OOH})_{4}\end{array}$ \\
\hline 489 & 486 & $\begin{array}{l}\mathrm{C}_{15} \mathrm{H}_{23} \mathrm{O}_{14} \\
\mathrm{C}_{15} \mathrm{H}_{23} \mathrm{O}_{14}\end{array}$ & $\begin{array}{ll}\text { simple AutOx. } & (22 \%) \\
\text { ext. AutOx. } & (78 \%)\end{array}$ & $\begin{array}{l}\mathrm{O}, \mathrm{O}-\mathrm{C}_{15} \mathrm{H}_{18}(\mathrm{OOH})_{5} \mathrm{O}_{2} \\
\mathrm{O}, \mathrm{O}-\mathrm{C}_{15} \mathrm{H}_{19}(\mathrm{OO})(\mathrm{OOH})_{4} \mathrm{O}_{2}\end{array}$ & \\
\hline
\end{tabular}

The change of the detection sensitivity for different HOMs (especially for those containing a single hydroperoxide moiety) leads to a different contribution of the individual product groups to the total HOM signal intensities when changing from nitrate ionization to acetate ionization. For acetate ionization, the ext. AutOx. $-\mathrm{CO}_{2}$ group contributes $50 \%$, the simple AutOx. group $35 \%$ and the ext. AutOx. group only $15 \%$ to the estimated total molar HOM yield. Thus, the simple AutOx. group contributes $29 \%$ to the estimated total molar HOM yield when detecting with nitrate ionization and with $35 \%$ when detecting with acetate ionization. Further detail regarding the HOM concentration calculations can be found in the Supplement. The values are based on the lowerlimit concentration calculations and on the different detection sensitivities of the different reagent ions, which depend, e.g. on the number of hydroperoxide moieties in the molecule of interest. Hence, a quantitative statement concerning the contributions of the three reaction product groups is difficult. However, the two new product groups ext. AutOx. and ext. AutOx. $-\mathrm{CO}_{2}$ are crucial for the explanation of HOM formation from the ozonolysis of $\beta$-caryophyllene.

\subsection{Experiments with isotopically labelled ozone $\left({ }^{18} \mathrm{O}_{3}\right)$}

The signal assignment of the three reaction product groups was supported by experiments using isotopically labelled ozone, ${ }^{18} \mathrm{O}_{3}$. When changing from ${ }^{16} \mathrm{O}_{3}$ to ${ }^{18} \mathrm{O}_{3}$ in the ozonolysis, the product signals in the mass spectra were shifted by two nominal mass units for each oxygen arising from the initial ozone attack (Jokinen et al., 2014). The concentration of remaining ${ }^{18} \mathrm{O}_{2}$ in the carrier gas was about $0.05 \%$ of the total $\mathrm{O}_{2}$ concentration. Hence, ${ }^{18} \mathrm{O}_{2}$ cannot compete with ${ }^{16} \mathrm{O}_{2}$ in the autoxidation steps. Thus, the isotopically labelled ${ }^{18} \mathrm{O}$ atoms will stem from the ozone attack at the double bond.

For example, Fig. 2 shows a comparison of results from an experiment using either ${ }^{18} \mathrm{O}_{3}$ or ${ }^{16} \mathrm{O}_{3}$ in the ozonolysis reaction for otherwise constant reaction conditions. The spectra in the range $340-400 \mathrm{Th}$ are dominated by four signals of $\mathrm{RO}_{2}$ radicals at the nominal mass-to-charge ratio of 346 , 358,378 and $390 \mathrm{Th}$, representing signals of all three product groups. The signals at nominal 358 and $390 \mathrm{Th}$ were shifted by four nominal mass units when changing from ${ }^{16} \mathrm{O}_{3}$ to 


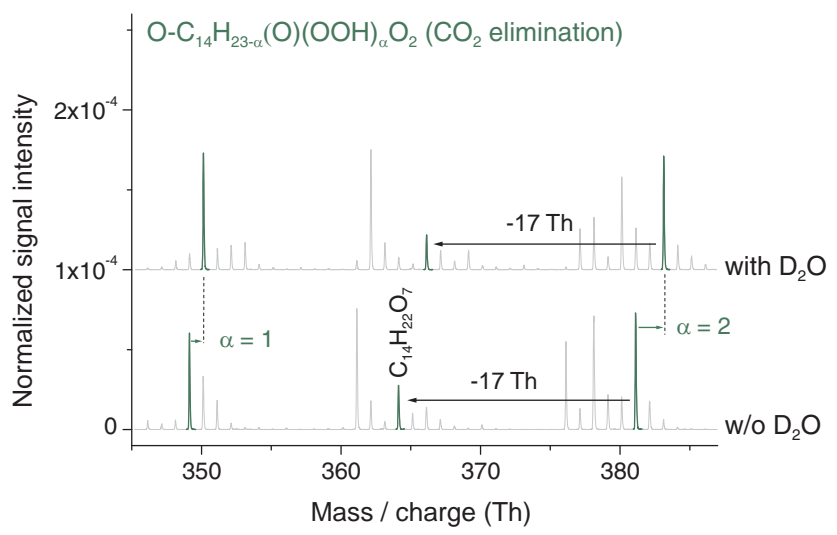

Figure 5. Ozonolysis of $\beta$-caryophyllene in the absence (lower part) and presence (upper part) of $\mathrm{D}_{2} \mathrm{O}$ applying nitrate ionization in the analysis. Highly oxidized $\mathrm{RO}_{2}$ radicals of the product group ext. AutOx. $-\mathrm{CO}_{2}, \mathrm{O}-\mathrm{C}_{14} \mathrm{H}_{23-\alpha}(\mathrm{O})(\mathrm{OOH})_{\alpha} \mathrm{O}_{2}$ with $\alpha=1$ and 2, and the corresponding closed-shell product $\left(\mathrm{C}_{14} \mathrm{H}_{22} \mathrm{O}_{7}\right)$ of the $\mathrm{RO}_{2}$ radical with $\alpha=2$ are highlighted in green. The addition of $\mathrm{D}_{2} \mathrm{O}$ leads to an H/D exchange of the acidic $\mathrm{H}$ atoms being equal to the number of hydroperoxide groups in the molecules, i.e. a shift by one nominal mass unit for $\alpha=1$ or a shift by two nominal mass units for $\alpha=2$ (including the corresponding closed-shell product). [ $\beta$ caryophyllene $]=8.3 \times 10^{10},\left[\mathrm{O}_{3}\right]=1.02 \times 10^{12}$ molecules $\mathrm{cm}^{-3}$, reaction time is $7.9 \mathrm{~s}$.

${ }^{18} \mathrm{O}_{3}$. This shift indicates the presence of two oxygen atoms in these reaction products from the initial ozone reaction. The signal at nominal $358 \mathrm{Th}$ is attributed to a $\mathrm{RO}_{2}$ radical from the simple AutOx. group, the signal at nominal $390 \mathrm{Th}$ contains contributions from products of the simple AutOx. as well as the ext. AutOx. group (a further differentiation by means of $\mathrm{H} / \mathrm{D}$ exchange experiments is described later). The signal shift by four nominal mass units shows that reaction products from both product groups contain two oxygen atoms from the initial ozone attack O,O- as stated in the general formulas $\mathrm{O}, \mathrm{O}-\mathrm{C}_{15} \mathrm{H}_{23-x}(\mathrm{OOH})_{x} \mathrm{O}_{2}$ with $x=1-$ 5 (simple AutOx.) and $\mathrm{O}, \mathrm{O}-\mathrm{C}_{15} \mathrm{H}_{23-y}(\mathrm{OO})(\mathrm{OOH})_{y} \mathrm{O}_{2}$ with $y=1-4$ (ext. AutOx.). The third oxygen atom from the attacking ozone is the oxygen atom of the $\mathrm{OH}$ radical that was split off from the Criegee intermediate forming the alkyl radicals $4 a-4 c$ as shown in the first steps of the ozonolysis mechanism in Fig. 6. Further possible reaction pathways of species $4 \mathrm{~b}$ forming simple AutOx. and ext. AutOx. reaction products are proposed in Fig. 7.

The signals at nominal 346 and $378 \mathrm{Th}$ were shifted by two nominal mass units applying either ${ }^{16} \mathrm{O}_{3}$ or ${ }^{18} \mathrm{O}_{3}$. Consequently, only one oxygen atom from the initial ozone attack remains in these reaction products and a second oxygen atom from the initial ozone attack must have been abstracted in the course of the product formation. The position and the exact mass-to-charge ratio of these $\mathrm{RO}_{2}$ signals in the mass spectra suggest that the $\mathrm{RO}_{2}$ radicals contain only 14 carbon atoms. The loss of one carbon atom and one more oxygen atom from the initial ozone attack points to an elimination of $\mathrm{CO}$ or $\mathrm{CO}_{2}$ in these molecules. The elimination of $\mathrm{CO}$ from highly oxidized $\mathrm{RO}_{2}$ radicals was proposed for reaction products from the ozonolysis of cyclohexene (Berndt et al., 2015b). The corresponding reaction products from the ozonolysis of $\beta$-caryophyllene including $\mathrm{CO}$ elimination were detected in small yields at nominal 365,397 and $429 \mathrm{Th}$ using nitrate ionization and were not further investigated here.

On the other hand, the formation of reaction products from the third product group is supposed to involve $\mathrm{CO}_{2}$ elimination starting from species 7 in Fig. 8. Species 7 contains an acyl peroxy radical functional group which might react with the double bond under formation of an acyl alkoxy radical 15 . From this acyl alkoxy radical, $\mathrm{CO}_{2}$ can easily be released (Jaoui et al., 2003; Winterhalter et al., 2009). Therefore, the reaction product at nominal $346 \mathrm{Th}$ can be explained by an elimination of $\mathrm{CO}_{2}$ (-44 nominal mass units) and a subsequent $\mathrm{O}_{2}$ addition ( +32 nominal mass units). Reaction products with signals at nominal 378 and $420 \mathrm{Th}$ can be formed by further $\mathrm{O}_{2}$ insertion via autoxidation starting from 17; see Fig. 8. Based on these results, $\mathrm{CO}_{2}$ elimination was proposed for reaction products from the third product group, named "ext. AutOx. - $\mathrm{CO}_{2}$ ". Products of this group can be explained by the general formula $\mathrm{O}-\mathrm{C}_{14} \mathrm{H}_{23-\alpha}(\mathrm{O})(\mathrm{OOH})_{\alpha} \mathrm{O}_{2}$ with $\alpha=$ $1-3$. Here, $\mathrm{O}-$ stands for the remaining oxygen atom from the reacting ozone. The proposed reaction mechanism for the formation of the first member of the ext. AutOx. $-\mathrm{CO}_{2}$ group with $\alpha=1$ is given in Fig. 8, $7^{\prime} \rightarrow 15 \rightarrow 16 \rightarrow 17$. It tentatively includes the formation of an epoxide ring. The corresponding oxygen atom is marked as $(\mathrm{O})$ in the general formula $\mathrm{O}-\mathrm{C}_{14} \mathrm{H}_{23-\alpha}(\mathrm{O})(\mathrm{OOH})_{\alpha} \mathrm{O}_{2}$. The marked oxygen atom, $(\mathrm{O})$, could also belong to an aldehyde or a ketone. However, it was not possible to explain the formation of a carbonyl functional group together with the $\mathrm{CO}_{2}$ elimination using known reaction mechanisms in the literature (Jaoui et al., 2003; Winterhalter et al., 2009). On the other hand, epoxide formation was already postulated for the $\mathrm{OH}$-radical-initiated oxidation of aromatic compounds (Andino et al., 1996; Bartolotti and Edney, 1995; Berndt and Böge, 2006; Ghigo and Tonachini, 1999; Suh et al., 2003). The explanation of the oxygen atom, $(\mathrm{O})$, by a hydroxy moiety can be excluded, because this would imply the presence of two more hydrogen atoms in the product and hence an increase of two nominal mass units in the mass spectrum. Furthermore, the possible presence of a hydroxy moiety would provide an additional acidic $\mathrm{H}$ atom in the molecule, which was not detected in H/D exchange experiments with heavy water (see Sect. 3.3).

\subsection{Experiments with heavy water $\left(\mathrm{D}_{2} \mathrm{O}\right)$}

A next set of experiments was conducted in the presence of heavy water $\left(\mathrm{D}_{2} \mathrm{O}\right)$, applying nitrate ionization; see Figs. 3, 4 , and 5. The addition of $\mathrm{D}_{2} \mathrm{O}$ leads to an $\mathrm{H} / \mathrm{D}$ exchange of all acidic $\mathrm{H}$ atoms present in the molecule (Rissanen et al., 2014) and thus, to a signal shift in the mass spectrum by a certain 


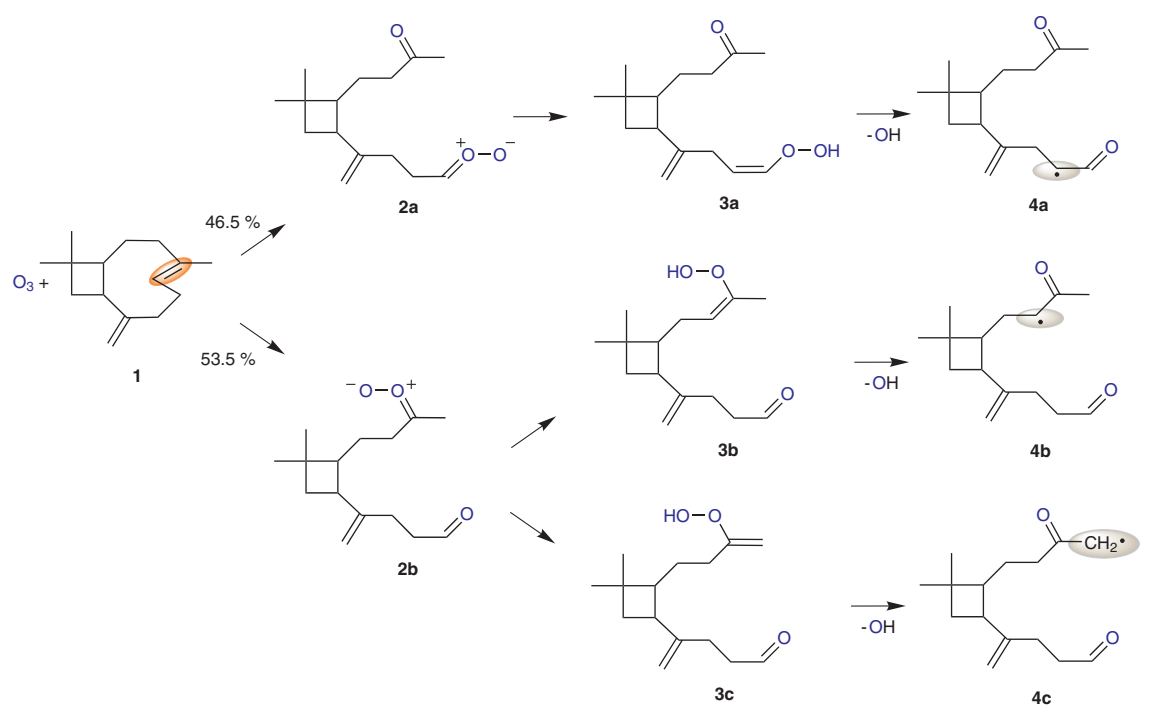

Figure 6. First reaction steps of the ozonolysis of $\beta$-caryophyllene. The attack of the more reactive endocyclic double bond (highlighted in orange) is exclusively demonstrated. Oxygen atoms arising from the attacking ozone are highlighted in blue, the alkyl radical functional groups with a shaded oval.

number of nominal mass units being equal to the number of acidic $\mathrm{H}$ atoms in the molecule. For HOMs following the simple autoxidation process, all oxygen molecules inserted into the molecule, except the $\mathrm{RO}_{2}$ radical functional group, are present as hydroperoxide moieties. The resulting signal shift in the presence of $\mathrm{D}_{2} \mathrm{O}$ corresponds to the number of hydroperoxide moieties as shown for the HOMs from the ozonolysis of cyclohexene (Berndt et al., 2015b; Rissanen et al., 2014) and $\alpha$-cedrene (Richters et al., 2016).

Figure 3 shows mass spectra in the presence and absence of $\mathrm{D}_{2} \mathrm{O}$ focusing on the signals at nominal 393, 408 and $425 \mathrm{Th}$ which were assigned to reaction products of the simple AutOx. and ext. AutOx. groups. The full spectra in the nominal mass-to-charge range 360-495 Th are shown in Fig. 4. In the presence of $\mathrm{D}_{2} \mathrm{O}$, all three signals were split up into two signals according to their numbers of acidic $\mathrm{H}$ atoms in the molecules. This behaviour indicates that two different reaction products contribute to each signal. The signal at nominal $393 \mathrm{Th}$ corresponds to the $\mathrm{RO}_{2}$ radical $\mathrm{C}_{15} \mathrm{H}_{23} \mathrm{O}_{8}$ and was shifted by one or two nominal mass units when adding $\mathrm{D}_{2} \mathrm{O}$. Two of the eight oxygen atoms arise from the initial ozone attack (see Sect. 3.2) and two oxygen atoms represent the $\mathrm{RO}_{2}$ radical functional group. Consequently, two oxygen molecules (four oxygen atoms) at the maximum can exist in hydroperoxide groups indicated by a signal shift of two nominal mass units. The corresponding product belongs to the simple AutOx. group, $\mathrm{O}, \mathrm{O}-\mathrm{C}_{15} \mathrm{H}_{23-x}(\mathrm{OOH})_{x} \mathrm{O}_{2}$ with $x=2$, species 11 in Fig. 8. The signal intensity of the signal, shifted by two nominal mass units, accounts for $31 \%$ of the total signal intensity; see the red peak at nominal $395 \mathrm{Th}$. On the other hand, the signal shift by one nominal mass unit less (blue peak at nominal $394 \mathrm{Th}$ ) can only be ex- plained by an oxygen molecule insertion without forming a hydroperoxide group. This insertion is tentatively explained by an endoperoxide formation from the internal reaction of a $\mathrm{RO}_{2}$ radical with the second, still intact, double bond in the molecule; see reaction sequence $5^{\prime} \rightarrow 8 \rightarrow 9$ in Fig. 7 and $7^{\prime} \rightarrow 13 \rightarrow 14$ in Fig. 8. The signal intensity of this reaction product from the extended autoxidation mechanism ext. AutOx., $\mathrm{O}, \mathrm{O}-\mathrm{C}_{15} \mathrm{H}_{23-y}(\mathrm{OO})(\mathrm{OOH})_{y} \mathrm{O}_{2}$ with $y=1$, accounts for $69 \%$ of the total intensity of the shifted peaks. The group, $(\mathrm{OO})$, in the formula stands for the inserted oxygen molecule appearing as the postulated endoperoxide; see species 14 in Fig. 8.

The signal of the $\mathrm{RO}_{2}$ radical at nominal $425 \mathrm{Th}$ was shifted by three and two nominal mass units accounting for 29 and $71 \%$ of the total signal intensity respectively. Here, compared to the reaction products appearing at nominal $393 \mathrm{Th}$, a next oxygen molecule was inserted in the products resulting in a third hydroperoxide group in simple AutOx., O,O- $\mathrm{C}_{15} \mathrm{H}_{23-x}(\mathrm{OOH})_{x} \mathrm{O}_{2}$ with $x=3$ and a second hydroperoxide group in ext. AutOx., $\mathrm{O}, \mathrm{O}-\mathrm{C}_{15} \mathrm{H}_{23-y}(\mathrm{OO})(\mathrm{OOH})_{y} \mathrm{O}_{2}$ with $y=1$. The signal of the corresponding closed-shell product to the $\mathrm{RO}_{2}$ radical at nominal $425 \mathrm{Th}$ is visible at nominal $408 \mathrm{Th}$. It shows the same signal shift as its corresponding $\mathrm{RO}_{2}$ radical by three or two nominal mass units. The signal intensity of the closed-shell product from the simple AutOx. group, O,O$\mathrm{C}_{15} \mathrm{H}_{22-x} \mathrm{O}(\mathrm{OOH})_{x}$ with $x=3$ accounting for $30 \%$ of the total signal intensity of the shifted peaks (red peak at nominal $411 \mathrm{Th}$ ), the signal intensity of the reaction product from the ext. AutOx. group, $\mathrm{O}, \mathrm{O}-\mathrm{C}_{15} \mathrm{H}_{22-y} \mathrm{O}(\mathrm{OO})(\mathrm{OOH})_{y} \mathrm{O}_{2}$ with $y=2$ (blue peak at $410 \mathrm{Th}$ ) accounts for $70 \%$. 


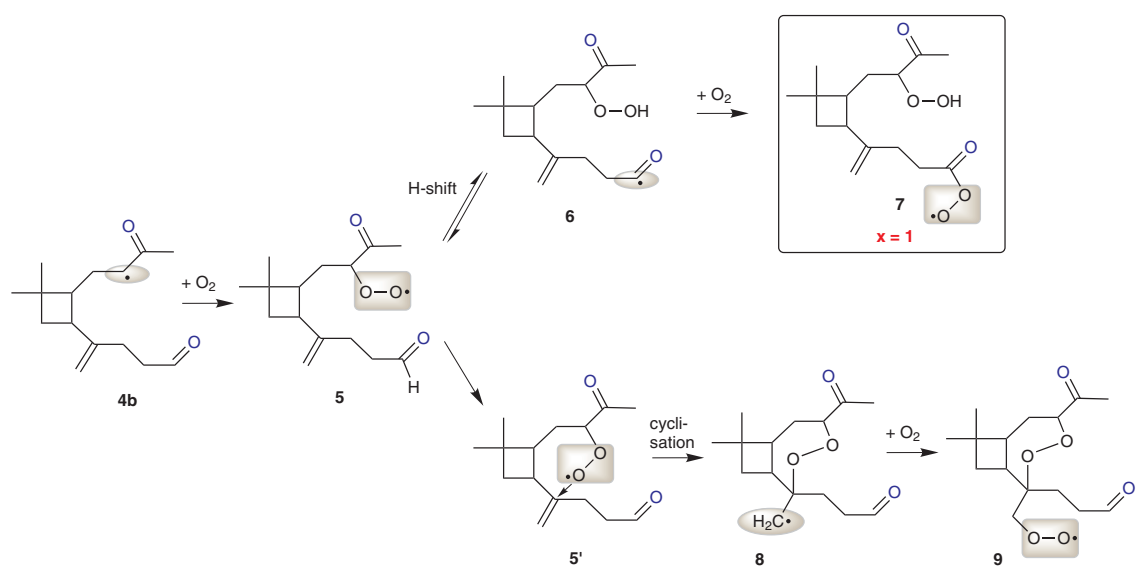

Figure 7. Further reaction steps of the alkyl radical 4b. Oxygen atoms arising from the attacking ozone are highlighted in blue, alkyl radical functional groups with a shaded oval and $\mathrm{RO}_{2}$ radical functional groups with a shaded rectangle. Detected species are surrounded by a solid rectangle. The stated position, where the internal $\mathrm{H}$-transfer takes place $5 \rightarrow 6$, represents an example only.

The relative contributions of the two product groups to the total signal intensity for all signals are summarized in Table 1 . With the exception of the signal at nominal $376 \mathrm{Th}$, the ratio of the contributions of the two product groups is simple AutOx. / ext. AutOx. $=3 / 7-2 / 8$. This ratio shows that the extended autoxidation mechanism is more important than the simple autoxidation mechanism for reaction products from the ozonolysis of $\beta$-caryophyllene.

It is to be noted that a similar signal splitting-up was detected in H/D exchange experiments from the ozonolysis of $\alpha$-pinene by Rissanen et al. (2015). Here, the authors proposed amongst others an endoperoxide formation as well based on the literature data from the $\mathrm{OH}$-radical-initiated oxidation of aromatic compounds and pinenes (Andino et al., 1996; Bartolotti and Edney, 1995; Vereecken and Peeters, 2004). Figure 5 shows a comparison of spectra in the nominal mass-to-charge range 345-385 Th recorded in the presence and absence of $\mathrm{D}_{2} \mathrm{O}$. The detected signals at nominal 349, 364 and 381 Th are assigned to the third product group ext. AutOx $-\mathrm{CO}_{2}$. The signal at nominal $349 \mathrm{Th}$ was shifted by one nominal mass unit when adding $\mathrm{D}_{2} \mathrm{O}$, which indicates the presence of one hydroperoxide moiety in this reaction product. This signal has the molecular formula $\mathrm{C}_{14} \mathrm{H}_{23} \mathrm{O}_{6}$ and one of the six oxygen atoms arises from the initial ozone attack as observed from the experiments with isotopically labelled ozone; see Sect. 3.2. Two oxygen atoms are assigned to the $\mathrm{RO}_{2}$ radical functional group. The signal shift by one nominal mass unit from the H/D exchange experiment indicates that two of the three remaining oxygen atoms form a hydroperoxide moiety. The third residual oxygen atom must be inserted into the molecule without generating an additional acidic $\mathrm{H}$ atom, illustrated by $(\mathrm{O})$ in the general formula $\mathrm{O}-\mathrm{C}_{14} \mathrm{H}_{23-\alpha}(\mathrm{O})(\mathrm{OOH})_{\alpha} \mathrm{O}_{2}$. The chemical nature of this $(\mathrm{O})$ in the product is still uncertain and was tentatively attributed to an epoxide formation at the sec- ond double bond; see $7^{\prime} \rightarrow 15$ in Fig. 8 and the discussion in the Section before (Sect. 3.2). The position of the $\mathrm{RO}_{2}$ radical signal of $\mathrm{O}-\mathrm{C}_{14} \mathrm{H}_{23-\alpha}(\mathrm{O})(\mathrm{OOH})_{\alpha} \mathrm{O}_{2}$ with $\alpha=2$ at nominal $381 \mathrm{Th}$ and its corresponding closed-shell product $\mathrm{C}_{14} \mathrm{H}_{22} \mathrm{O}_{7}$ at nominal $364 \mathrm{Th}$ were shifted by two nominal mass units in the presence of $\mathrm{D}_{2} \mathrm{O}$. The insertion of the next oxygen molecule leads to the formation of the $\mathrm{RO}_{2}$ radical $\mathrm{O}-\mathrm{C}_{14} \mathrm{H}_{23-\alpha}(\mathrm{O})(\mathrm{OOH})_{\alpha} \mathrm{O}_{2}$ with $\alpha=3$ detected at nominal $413 \mathrm{Th}$, and its closed-shell product at nominal $396 \mathrm{Th}$. Both signals were shifted by three nominal mass units in the presence of $\mathrm{D}_{2} \mathrm{O}$. Signals of reaction products from the ext. AutOx. $-\mathrm{CO}_{2}$ group with more than 10 oxygen atoms and more than three hydroperoxide moieties were not detected.

\subsection{Mechanism of HOM formation}

Figures 6-8 show the proposed initial reaction steps of the ozonolysis of $\beta$-caryophyllene with a focus on the HOM formation. The reaction is initiated by the ozone attack at the more reactive, endocyclic double bond of $\beta$-caryophyllene 1 marked by the orange oval in Fig. 6 . The rate coefficient of the reaction of ozone with the endocyclic double bond is about 100 times higher than that of the exocyclic double bond (Winterhalter et al., 2009). Therefore, the reaction of ozone with the exocyclic double bond is neglected here. The reaction of ozone with a double bond is exothermic and forms carbonyl oxides, the so-called Criegee intermediates (CIs), $2 \mathrm{a}$ and $2 \mathrm{~b}$ (Criegee, 1975). Due to the reaction exothermicity, the CIs initially exist with a large amount of excess energy (chemically activated CIs), which is stepwise lost by collisions with the bath gas molecules (Kroll et al., 2001). CIs with an internal energy below a definite threshold energy, needed for prompt decomposition, are called stabilized CIs (Vereecken and Francisco, 2012). Both stabilized and chemically activated CIs can undergo unimolecular reactions or can be further collisionally stabilized by the bath gas (Kroll et al., 


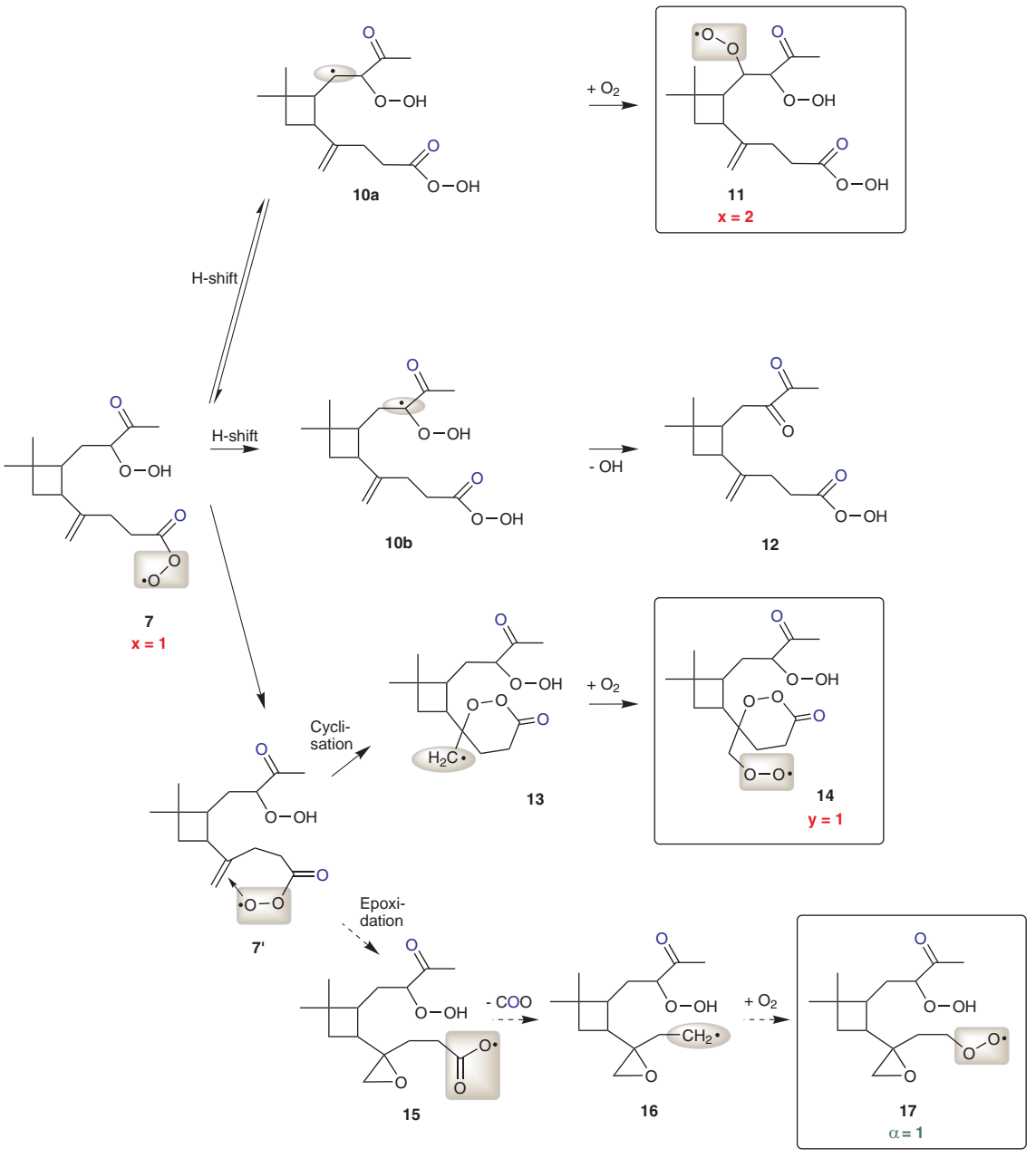

Figure 8. Further reaction steps of the $\mathrm{RO}_{2}$ radical (7). Oxygen atoms arising from the attacking ozone are highlighted in blue, alkyl radical functions with a shaded oval and $\mathrm{RO}_{2}$ radical functional groups with a shaded rectangle. Detected species are surrounded by a solid rectangle. The stated position, where the internal H-transfer takes place $7 \rightarrow 10 \mathrm{a}$, represents an example only. The dashed arrows indicate that the stated reaction pathway remains uncertain.

2001; Vereecken et al., 2012). Stabilized CIs can also react in a variety of bimolecular reactions depending on their molecular structure (Vereecken et al., 2012). An important unimolecular isomerization step gives the corresponding vinyl hydroperoxide 3a, 3b and 3c (Drozd et al., 2011; Kroll et al., 2001; Vereecken et al., 2012), which further decomposes under $\mathrm{OH}$ radical release and formation of the alkyl radicals $4 \mathrm{a}, 4 \mathrm{~b}$ and $4 \mathrm{c}$. For simplicity, the reaction scheme does not differentiate between excited and stabilized molecules.

Figure 7 focuses on further reaction pathways of the alkyl radical $4 \mathrm{~b}$. It is supposed that $4 \mathrm{a}$ and $4 \mathrm{c}$ are reacting similarly. Molecular oxygen rapidly adds to $4 \mathrm{~b}$ forming the first $\mathrm{RO}_{2}$ radical 5. Species 5 can either react via an intramolecular $\mathrm{H}$-transfer, $5 \rightarrow 6$, followed by $\mathrm{O}_{2}$ addition forming the $\mathrm{RO}_{2}$ radical 7 from the product group simple AutOx., O,O$\mathrm{C}_{15} \mathrm{H}_{23-x}(\mathrm{OOH})_{x} \mathrm{O}_{2}$ with $x=1$ or can internally attack the remaining double bond, forming an endoperoxide and an alkyl radical, $5 \rightarrow 5^{\prime} \rightarrow 8$, and after $\mathrm{O}_{2}$ addition, the $\mathrm{RO}_{2}$ radical 9. This cyclization leads to an $\mathrm{O}_{2}$ insertion without forming a hydroperoxide moiety, indicated by $(\mathrm{OO})$ in the formula $\mathrm{O}, \mathrm{O}-\mathrm{C}_{15} \mathrm{H}_{23-y}(\mathrm{OO})(\mathrm{OOH})_{y} \mathrm{O}_{2}$ of the product group ext. AutOx. (OO) represents the endoperoxide group. The $\mathrm{RO}_{2}$ radical 9 can be further oxidized via the autoxidation mechanism forming $\mathrm{RO}_{2}$ radicals belonging to the product group ext. AutOx., $\mathrm{O}, \mathrm{O}-\mathrm{C}_{15} \mathrm{H}_{23-y}(\mathrm{OO})(\mathrm{OOH})_{y} \mathrm{O}_{2}$ with $y=1-4$, not shown here. A similar endoperoxide formation was already predicted for the $\mathrm{OH}$ radical-initiated oxidation of aromatic compounds (Andino et al., 1996; Bartolotti and Edney, 1995; Berndt and Böge, 2006; Ghigo and Tonachini, 1999; Suh et al., 2003). Berndt et al. (2015b) validated the formation of endoperoxide-group containing $\mathrm{RO}_{2}$ radicals from the $\mathrm{OH}$ radical-initiated oxidation of mesitylene (1,3,5-trimethylbenzene) based on the detection of accretion products of these $\mathrm{RO}_{2}$ radicals. Endoperoxide for- 
mation was also proposed from theoretical investigations for the reaction of $\mathrm{OH}$ radicals with the monoterpenes $\alpha$ - and $\beta$-pinene (Vereecken et al., 2007; Vereecken and Peeters, 2004,2012 ) and tentatively confirmed in chamber experiments (Eddingsaas et al., 2012).

Figure 8 shows the further reaction pathways of the $\mathrm{RO}_{2}$ radical 7 from the simple AutOx. group, O,O$\mathrm{C}_{15} \mathrm{H}_{23-x}(\mathrm{OOH})_{x} \mathrm{O}_{2}$ with $x=1$. The step $7 \rightarrow 10 \mathrm{a} \rightarrow 11$ is an intramolecular $\mathrm{H}$-transfer with subsequent $\mathrm{O}_{2}$ addition under formation of the $\mathrm{RO}_{2}$ radical 11, O,O$\mathrm{C}_{15} \mathrm{H}_{23-x}(\mathrm{OOH})_{x} \mathrm{O}_{2}$ with $x=2$ (simple AutOx.). Furthermore, the closed-shell product 12 can be formed via intramolecular $\mathrm{H}$-transfer and subsequent $\mathrm{OH}$ radical elimination, $7 \rightarrow 10 \mathrm{~b} \rightarrow 12$. The formation of HOMs from the ext. AutOx. group can be explained by the internal $\mathrm{RO}_{2}$ radical reaction with the remaining double bond. This might lead to the cyclization product 13 that subsequently adds $\mathrm{O}_{2}$ forming the next $\mathrm{RO}_{2}$ radical $14, \mathrm{O}, \mathrm{O}-\mathrm{C}_{15} \mathrm{H}_{23-y}(\mathrm{OO})(\mathrm{OOH})_{y} \mathrm{O}_{2}$ with $y=1$.

The formation of HOMs from the product group ext. AutOx. $-\mathrm{CO}_{2}$ is uncertain at the moment. A possible reaction sequence starting from the $\mathrm{RO}_{2}$ radical 7 is shown in Fig. $8,7 \rightarrow 7^{\prime} \rightarrow 15 \rightarrow 16 \rightarrow 17$. In this reaction mechanism an epoxidation step is proposed, $7^{\prime} \rightarrow 15$. Subsequently, $\mathrm{CO}_{2}$ is eliminated from the acyl alkoxy radical functional group, $15 \rightarrow 16$, resulting in an alkyl radical 16 that rapidly adds $\mathrm{O}_{2}$ forming the $\mathrm{RO}_{2}$ radical 17 . This new $\mathrm{RO}_{2}$ radical $17, \mathrm{O}-$ $\mathrm{C}_{14} \mathrm{H}_{23-\alpha}(\mathrm{O})(\mathrm{OOH})_{\alpha} \mathrm{O}_{2}$ with $\alpha=1$, can further react via autoxidation, i.e. intramolecular $\mathrm{H}$-transfer and subsequent $\mathrm{O}_{2}$ addition, forming the next $\mathrm{RO}_{2}$ radicals of the ext. AutOx. $\mathrm{CO}_{2}$ group with $\alpha=2$ and 3 .

The epoxide formation cannot be proven and represents only a proposed reaction pathway in order to explain the experimental results. A similar epoxide formation step was postulated for the $\mathrm{OH}$ radical-initiated oxidation of aromatic compounds (Bartolotti and Edney, 1995; Glowacki et al., 2009; Motta et al., 2002; Pan and Wang, 2014; Suh et al., 2003; Yu and Jeffries, 1997). Possible reaction products, e.g. epoxide carbonyls, were detected in small quantities using GC-MS analysis (Glowacki et al., 2009; Yu and Jeffries, 1997).

Figures 6-8 show the proposed reaction paths leading to the first $\mathrm{RO}_{2}$ radicals of all three product groups. Consecutive oxidation processes lead to the next $\mathrm{RO}_{2}$ radicals in competition to bimolecular reactions like $\mathrm{RO}_{2}+\mathrm{R}^{\prime} \mathrm{O}_{2}$, or $\mathrm{RO}_{2}+\mathrm{NO}$. The formation of first-generation closed-shell products from highly oxidized $\mathrm{RO}_{2}$ radicals is discussed by Jokinen et al. (2014) and is not included here.

\subsection{Experiment with addition of the SCI scavenger $\mathrm{CH}_{3} \mathrm{COOH}$}

A measurement series in the presence of acetic acid $\left(\mathrm{CH}_{3} \mathrm{COOH}\right)$ has been conducted in order to get an indication of whether the HOM formation starts from the chem-

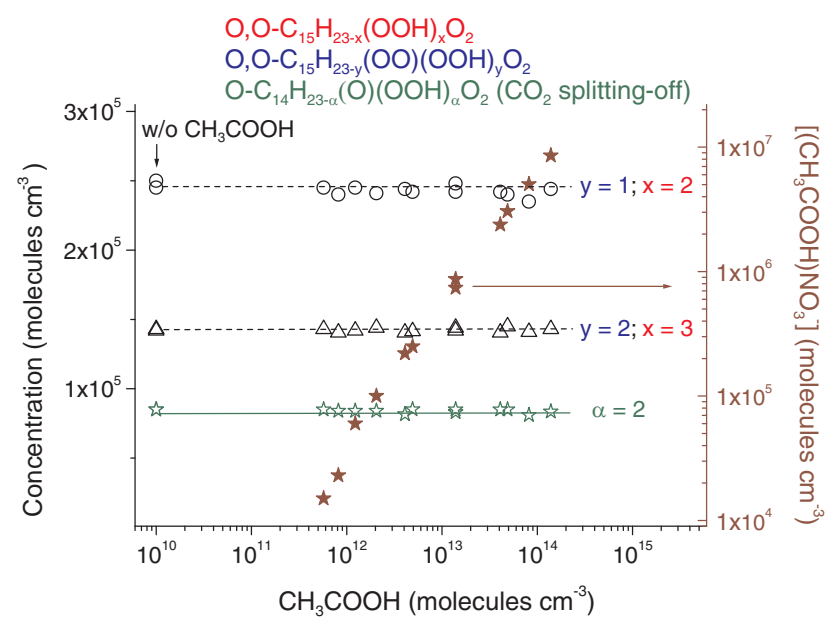

Figure 9. Highly oxidized $\mathrm{RO}_{2}$ radicals from the ozonolysis of $\beta$-caryophyllene from the three product groups, simple AutOx. with $\mathrm{O}, \mathrm{O}-\mathrm{C}_{15} \mathrm{H}_{23-x}(\mathrm{OOH})_{x} \mathrm{O}_{2}, x=2$ and 3 , ext. AutOx. with $\mathrm{O}, \mathrm{O}-\mathrm{C}_{15} \mathrm{H}_{23-y}(\mathrm{OO})(\mathrm{OOH})_{y} \mathrm{O}_{2}, y=1$ and 2 , and ext. AutOx. $\mathrm{CO}_{2}$ with $\mathrm{O}-\mathrm{C}_{14} \mathrm{H}_{23-\alpha}(\mathrm{O})(\mathrm{OOH})_{\alpha} \mathrm{O}_{2}, \alpha=2$ as a function of the $\mathrm{CH}_{3} \mathrm{COOH}$ concentration. $\mathrm{CH}_{3} \mathrm{COOH}$ acts as a sCI scavenger. The black-coloured data points stand for the $\mathrm{RO}_{2}$ radicals from the simple AutOx. group and from the ext. AutOx. group with $x=2$ and $y=1$ (circle) as well as with $x=3$ and $y=2$ (triangle). The adduct $\left(\mathrm{CH}_{3} \mathrm{COOH}\right) \mathrm{NO}_{3}^{-}$was detected with lower-limit concentrations which are a factor of $2 \times 10^{7}$ lower than the acetic acid concentration in the tube. $[\beta$-caryophyllene $]=8.3 \times 10^{10}$, $\left[\mathrm{O}_{3}\right]=4.7 \times 10^{10},\left[\mathrm{CH}_{3} \mathrm{COOH}\right]=(0-1.4) \times 10^{14}$ molecules cm $\mathrm{cm}^{-3}$; reaction time is $7.9 \mathrm{~s}$.

ically activated CI or from the collisionally stabilized CI (sCI), species $2 a$ and $2 b$ in Fig. 9. Small organic acid were found to efficiently react with sCIs (Beck et al., 2011; Neeb et al., 1996) while chemically activated CIs exclusively react via unimolecular reactions, and bimolecular reactions with other species (such as acids) can be neglected (Vereecken and Francisco, 2012); see also Sect. 3.4.

Figure 9 shows the concentrations of three highly oxidized $\mathrm{RO}_{2}$ radicals from the three product groups as a function of the acetic acid $\left(\mathrm{CH}_{3} \mathrm{COOH}\right)$ concentration in the reaction gas. These measurements were performed by applying nitrate ionization. Additionally, also acetic acid was detectable by the $\left(\mathrm{CH}_{3} \mathrm{COOH}\right) \mathrm{NO}_{3}^{-}$adduct. The stated (lower limit) adduct concentrations are by a factor of $2 \times$ $10^{7}$ smaller than the acetic acid concentration in the reaction gas. Even for the highest $\mathrm{CH}_{3} \mathrm{COOH}$ concentrations of $1.4 \times 10^{14}$ molecules $\mathrm{cm}^{-3}$, no influence of the HOM concentrations on the acid concentration was detected (Fig. 9).

The absolute rate coefficient of the reaction of acetic acid with sCIs $\left(\mathrm{CH}_{2} \mathrm{OO}\right.$ or $\left.\mathrm{CH}_{3} \mathrm{CHOO}\right)$ was measured at 4 torr and $298 \mathrm{~K}$ to $(1.2-$ $2.5) \times 10^{-10} \mathrm{~cm}^{3}$ molecule $\mathrm{s}^{-1} \quad$ (Welz et al., 2014). Assuming a value of $2 \times 10^{-10} \mathrm{~cm}^{3}$ molecule ${ }^{-1} \mathrm{~s}^{-1}$ for the rate coefficient of the reaction of acetic acid with 
the sCIs from $\beta$-caryophyllene ozonolysis, a sCI lifetime with respect to this reaction of $3.6 \times 10^{-5} \mathrm{~s}$ using $\left[\mathrm{CH}_{3} \mathrm{COOH}\right]=1.4 \times 10^{14}$ molecules $\mathrm{cm}^{-3}$ follows. The sCI lifetime with respect to the unimolecular reactions, $2 \mathrm{a} \rightarrow 3 \mathrm{a}$ and $2 \mathrm{~b} \rightarrow 3 \mathrm{~b} / \mathrm{c}$, is substantially longer with $4 \times 10^{-3} \mathrm{~s}$ assuming the kinetic data for the largest sCI $\left(\left(\mathrm{CH}_{3}\right)_{2} \mathrm{COO}\right)$ available in the literature (Olzmann et al., 1997). That means that for $\left[\mathrm{CH}_{3} \mathrm{COOH}\right]>10^{13}$ molecules $\mathrm{cm}^{-3}$, the fate of the sCIs is dominated by the reaction with $\mathrm{CH}_{3} \mathrm{COOH}$ and the formation of $3 a-3 c$, the expected precursors species of the HOMs, is suppressed. The absence of any effect of the HOM concentrations on the acetic acid concentration is taken as an indicator that the sCIs are not involved in the HOM formation. Consequently, the HOM formation is tentatively attributed to reactions starting from the chemically activated Criegee intermediates.

\subsection{Time dependence of $\mathrm{RO}_{2}$ radical formation}

All previous experiments were conducted with a reaction time of $7.9 \mathrm{~s}$. A variation of the reaction time allows a examination of the possible time dependence of the reaction processes.

Therefore, the reaction time was varied for constant initial conditions in the time range of 3.0-7.9 s using acetate ionization and the concentration changes of $\mathrm{RO}_{2}$ radical from all three product groups were investigated; see Fig. 10. All $\mathrm{RO}_{2}$ radical concentrations increased proportionally with time. That shows, firstly, that no significant $\mathrm{RO}_{2}$ radical consumption occurred at these reaction conditions. Secondly, the interconversion of all $\mathrm{RO}_{2}$ radicals, including the $\mathrm{RO}_{2}$ radicals from the ext. AutOx. group with a proposed endoperoxide formation and those from the ext. AutOx. $-\mathrm{CO}_{2}$ group with the proposed $\mathrm{CO}_{2}$ elimination, proceeds at a timescale of seconds, i.e. with a rate coefficient $\geq 1 \mathrm{~s}^{-1}$. The $\mathrm{RO}_{2}$ concentrations increased by a factor of 2.3-2.7 from the shortest to the longest reaction time, which is almost identical to the increase of the reaction time by a factor of 2.6. This finding differs from the results of an investigation of cyclohexene ozonolysis using the same experimental set-up where a concentration increase by a factor of 20-35 was detected when extending the reaction time from 1.5 to $7.9 \mathrm{~s}$ (Berndt et al., 2015b). This strong increase was explained by the presence of a rate-limited entrance channel for the highly oxidized $\mathrm{RO}_{2}$ radicals detected from the cyclohexene ozonolysis. A similar behaviour was not observed for the formation of highly oxidized $\mathrm{RO}_{2}$ radicals from $\beta$-caryophyllene ozonolysis.

\section{Conclusion}

Early reaction intermediates (mainly highly oxidized $\mathrm{RO}_{2}$ radicals) from the ozonolysis of $\beta$-caryophyllene were investigated in a free-jet flow system at ambient pressure and

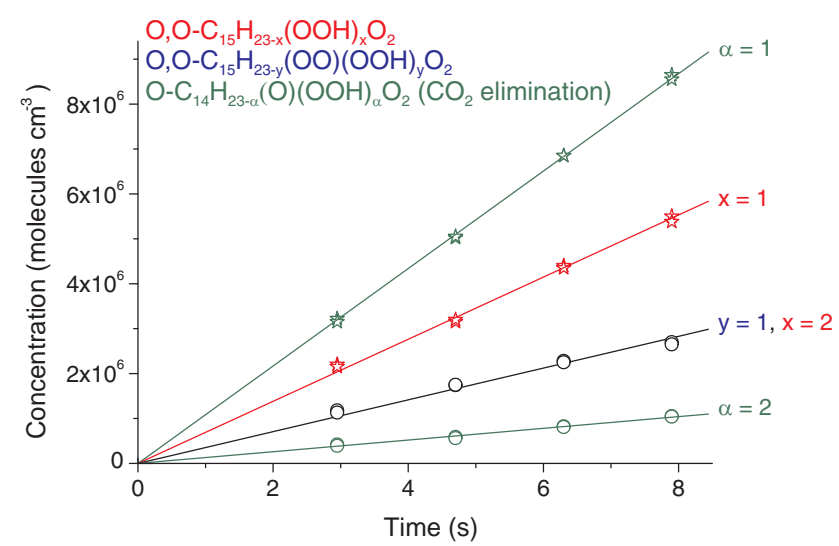

Figure 10. Time dependence of highly oxidized $\mathrm{RO}_{2}$ radical formation from the ozonolysis of $\beta$-caryophyllene using acetate ionization, data from the simple AutOx. group with $\mathrm{O}, \mathrm{O}-$ $\mathrm{C}_{15} \mathrm{H}_{23-x}(\mathrm{OOH})_{x} \mathrm{O}_{2}$ with $x=1$ and 2 (in red), from ext. AutOx. with $\mathrm{O}, \mathrm{O}-\mathrm{C}_{15} \mathrm{H}_{23-y}(\mathrm{OO})(\mathrm{OOH})_{y} \mathrm{O}_{2}$ with $y=1$ (in blue) and from ext. AutOx. $-\mathrm{CO}_{2}$ with $\mathrm{O}-\mathrm{C}_{14} \mathrm{H}_{23-\alpha}(\mathrm{O})(\mathrm{OOH})_{\alpha} \mathrm{O}_{2}$ with $\alpha=1$ and 2 (in green). The black-coloured data points (open circles) stand for the sum of the $\mathrm{RO}_{2}$ radical from the simple AutOx. group, $\mathrm{O}, \mathrm{O}-\mathrm{C}_{15} \mathrm{H}_{23-x}(\mathrm{OOH})_{x} \mathrm{O}_{2}$ with $x=2$ and from the ext. AutOx. group, $\mathrm{O}, \mathrm{O}-\mathrm{C}_{15} \mathrm{H}_{23-y}(\mathrm{OO})(\mathrm{OOH})_{y} \mathrm{O}_{2}$ with $y=1$. $[\beta$-caryophyllene $]=8.6 \times 10^{10},\left[\mathrm{O}_{3}\right]=3.1 \times 10^{11}$ molecules $\mathrm{cm}^{-3}$, reaction time is $3.0-7.9 \mathrm{~s}$.

a temperature of $295 \pm 2 \mathrm{~K}$ to study the formation mechanisms of highly oxidized multifunctional organic compounds (HOMs). The HOM formation from this reaction was recently studied in this laboratory (Richters et al., 2016). Different reaction products were detected which could not be assigned to the class of highly oxidized $\mathrm{RO}_{2}$ radicals formed via the "simple" autoxidation mechanism (Jokinen et al., 2014; Richters et al., 2016). This behaviour was attributed to the presence of a second double bond in $\beta$-caryophyllene which enables further reaction channels. These new insights in $\mathrm{RO}_{2}$ radical reaction pathways were investigated with the help of labelling experiments using heavy water and isotopically labelled ozone $\left({ }^{18} \mathrm{O}_{3}\right)$. The experimental results allowed to tentatively postulate extended autoxidation mechanisms including (i) the formation of an endoperoxide moiety in the $\mathrm{RO}_{2}$ radicals (ext. AutOx. group) and (ii) a $\mathrm{CO}_{2}$ elimination in presence of an unsaturated peroxy acyl radical (ext. AutOx. - $\mathrm{CO}_{2}$ group).

Time-dependent investigations of the formation of highly oxidized $\mathrm{RO}_{2}$ radicals showed that all $\mathrm{RO}_{2}$ radicals are formed on a timescale of less than $3 \mathrm{~s}$. Experiments with acetic acid, serving as a scavenger of stabilized Criegee intermediates, indicated that HOM formation most likely proceeds via reactions of the chemically excited Criegee intermediates formed as an early reaction product from the ozonolysis of $\beta$-caryophyllene.

In conclusion, this study provides insights in new reaction pathways that extend the autoxidation mechanism for unsat- 
urated $\mathrm{RO}_{2}$ radicals in the gas phase. About two thirds of the estimated total molar HOM yield from the ozonolysis of $\beta$ caryophyllene can be explained with the help of these new reaction pathways. Further work is needed to validate the proposed reaction steps of the extended autoxidation mechanism.

\section{Data availability}

The experimental data are available upon request from the corresponding author.

\section{The Supplement related to this article is available online at doi:10.5194/acp-16-9831-2016-supplement.}

Acknowledgements. We would like to thank K. Pielok and A. Rohmer for technical assistance and the German Academic Scholarship Foundation (Studienstiftung des deutschen Volkes) for funding.

Edited by: E. Browne

Reviewed by: three anonymous referees

\section{References}

Andino, J. M., Smith, J. N., Flagan, R. C., Goddard, W. A., and Seinfeld, J. H.: Mechanism of atmospheric photooxidation of aromatics: a theoretical study, J. Phys. Chem., 100, 10967-10980, 1996.

Bartolotti, L. J. and Edney, E. O.: Density functional theory derived intermediates from the $\mathrm{OH}$ initiated atmospheric oxidation of toluene, Chem. Phys. Lett., 245, 119-122, 1995.

Beck, M., Winterhalter, R., Herrmann, F., and Moortgat, G. K.: The gas-phase ozonolysis of $\alpha$-humulene, Phys. Chem. Chem. Phys., 13, 10970-11001, 2011.

Berezin, I. V., Denisov, E. T., and Emanuel, N. M.: The Oxidation of Cyclohexane, Pergamon Press, New York, 1996.

Berndt, T. and Böge, O.: Formation of phenol and carbonyls from the atmospheric reaction of $\mathrm{OH}$ radicals with benzene, Phys. Chem. Chem. Phys., 8, 1205-1214, 2006.

Berndt, T., Kaethner, R., Voigtländer, J., Stratmann, F., Pfeifle, M., Reichle, P., Sipilä, M., Kulmala, M., and Olzmann, M.: Kinetics of the unimolecular reaction of $\mathrm{CH}_{2} \mathrm{OO}$ and the bimolecular reactions with the water monomer, acetaldehyde and acetone under atmospheric conditions, Phys. Chem. Chem. Phys., 17, 19862 19873, 2015a.

Berndt, T., Richters, S., Kaethner, R., Voigtländer, J., Stratmann, F., Sipilä, M., Kulmala, M., and Herrmann, H.: Gas-phase ozonolysis of cycloalkenes: formation of highly oxidized $\mathrm{RO}_{2}$ radicals and their reactions with $\mathrm{NO}, \mathrm{NO}_{2}, \mathrm{SO}_{2}$, and other $\mathrm{RO}_{2}$ radicals, J. Phys. Chem. A, 119, 10336-10348, 2015b.

Calogirou, A., Kotzias, D., and Kettrup, A.: Product analysis of the gas-phase reaction of $\beta$-caryophyllene with ozone, Atmos. Environ., 31, 283-285, 1997.
Calvert, J. G., Atkinson, R., Kerr, J. A., Madronich, S., Moortgat, G. K., Wallington, T. J., and Yarwood, G.: The Mechanisms of Atmospheric Oxidation of the Alkenes, Oxford University Press, Oxford UK, 2000.

Ciccioli, P., Brancaleoni, E., Frattoni, M., Di Palo, V., Valentini, R., Tirone, G., Seufert, G., Bertin, N., Hansen, U., Csiky, O., Lenz, R., and Sharma, M.: Emission of reactive terpene compounds from orange orchards and their removal by within-canopy processes, J. Geophys. Res., 104, 8077-8094, 1999.

Criegee, R.: Mechanism of ozonolysis, Angew. Chem., Int. Ed., 14, 745-752, 1975.

Crounse, J. D., Nielsen, L. B., Jørgensen, S., Kjaergaard, H. G., and Wennberg, P. O.: Autoxidation of organic compounds in the atmosphere, J. Phys. Chem. Lett., 4, 3513-3520, 2013.

Drozd, G. T., Kroll, J., and Donahue, N. M.: 2,3-Dimethyl-2-butene (TME) ozonolysis: pressure dependence of stabilized Criegee intermediates and evidence of stabilized vinyl hydroperoxides, J. Phys. Chem. A, 115, 161-166, 2011.

Duhl, T. R., Helmig, D., and Guenther, A.: Sesquiterpene emissions from vegetation: a review, Biogeosciences, 5, 761-777, doi:10.5194/bg-5-761-2008, 2008.

Eddingsaas, N. C., Loza, C. L., Yee, L. D., Seinfeld, J. H., and Wennberg, P. O.: $\alpha$-pinene photooxidation under controlled chemical conditions - Part 1: Gas-phase composition in low- and high-NO $\mathrm{N}_{x}$ environments, Atmos. Chem. Phys., 12, 6489-6504, doi:10.5194/acp-12-6489-2012, 2012.

Ehn, M., Kleist, E., Junninen, H., Petäjä, T., Lönn, G., Schobesberger, S., Dal Maso, M., Trimborn, A., Kulmala, M., Worsnop, D. R., Wahner, A., Wildt, J., and Mentel, Th. F.: Gas phase formation of extremely oxidized pinene reaction products in chamber and ambient air, Atmos. Chem. Phys., 12, 5113-5127, doi:10.5194/acp-12-5113-2012, 2012.

Ehn, M., Thornton, J. A., Kleist, E., Sipilä, M., Junninen, H., Pullinen, I., Springer, M., Rubach, F., Tillmann, R., Lee, B., LopezHilfiker, F., Andres, S., Acir, I. H., Rissanen, M., Jokinen, T., Schobesberger, S., Kangasluoma, J., Kontkanen, J., Nieminen, T., Kurtén, T., Nielsen, L. B., Jørgensen, S., Kjaergaard, H. G., Canagaratna, M., Maso, M. D., Berndt, T., Petäjä, T., Wahner, A., Kerminen, V. M., Kulmala, M., Worsnop, D. R., Wildt, J., and Mentel, T. F.: A large source of low-volatility secondary organic aerosol, Nature, 506, 476-479, 2014.

Finlayson-Pitts, B. J. and Pitts, J. N.: Atmospheric Chemistry, John Wiley \& Sons, New York, 1986.

Geron, C. D. and Arnts, R. R.: Seasonal monoterpene and sesquiterpene emissions from Pinus taeda and Pinus virginiana, Atmos. Environ., 44, 4240-4251, 2010.

Ghigo, G. and Tonachini, G.: From benzene to muconaldehyde: theoretical mechanistic investigation on some tropospheric oxidation channels, J. Am. Chem. Soc., 121, 8366-8372, 1999.

Glowacki, D. R., Wang, L., and Pilling, M. J.: Evidence of formation of bicyclic species in the early stages of atmospheric benzene oxidation, J. Phys. Chem. A, 113, 5385-5396, 2009.

Grosjean, D., Williams, E., Grosjean, E., Andino, J. M., and Seinfeld, J. H.: Atmospheric oxidation of biogenic hydrocarbons: reaction of ozone with $\beta$-pinene, D-limonene and transcaryophyllene, Environ. Sci. Technol., 27, 2754-2758, 1993.

Guenther, A., Hewitt, C. N., Erickson, D., Fall, R., Geron, C., Graedel, T., Harley, P., Klinger, L., Lerdau, M., McKay, W. A., Pierce, T., Scholes, B., Steinbrecher, R., Tallamraju, R., Taylor, 
J., and Zimmerman, P.: A global model of natural volatile organic compound emissions, J. Geophys. Res., 100, 8873-8892, 1995.

Guenther, A. B., Jiang, X., Heald, C. L., Sakulyanontvittaya, T., Duhl, T., Emmons, L. K., and Wang, X.: The Model of Emissions of Gases and Aerosols from Nature version 2.1 (MEGAN2.1): an extended and updated framework for modeling biogenic emissions, Geosci. Model Dev., 5, 1471-1492, doi:10.5194/gmd-51471-2012, 2012.

Helmig, D., Revermann, T., Pollmann, J., Kaltschmidt, O., Jiménez Hernández, A., Bocquet, F., and David, D.: Calibration system and analytical considerations for quantitative sesquiterpene measurements in air, J. Chromatogr. A, 1002, 193-211, 2003.

Horváth, E., Hoffer, A., Sebők, F., Dobolyi, C., Szoboszlay, S., Kriszt, B., and Gelencsér, A.: Microscopic fungi as significant sesquiterpene emission sources, J. Geophys. Res., 116, D16301, doi:10.1029/2010JD015523, 2011.

Hyttinen, N., Kupiainen-Määttä, O., Rissanen, M. P., Muuronen, M., Ehn, M., and Kurtén, T.: Modeling the charging of highly oxidized cyclohexene ozonolysis products using nitrate-based chemical ionization, J. Phys. Chem. A, 119, 6339-6345, 2015.

Jaoui, M., Leungsakul, S., and Kamens, R. M.: Gas and particle products distribution from the reaction of $\beta$-caryophyllene with ozone, J. Atmos. Chem., 45, 261-287, 2003.

Jaoui, M., Kleindienst, T. E., Docherty, K. S., Lewandowski, M., and Offenberg, J. H.: Secondary organic aerosol formation from the oxidation of a series of sesquiterpenes: $\alpha$-cedrene, $\beta$ caryophyllene, $\alpha$-humulene and $\alpha$-farnesene with $\mathrm{O}_{3}, \mathrm{OH}$ and $\mathrm{NO}_{3}$ radicals, Environ. Chem., 10, 178-193, 2013.

Jardine, K., Yañez Serrano, A., Arneth, A., Abrell, L., Jardine, A., van Haren, J., Artaxo, P., Rizzo, L. V., Ishida, F. Y., Karl, T., Kesselmeier, J., Saleska, S., and Huxman, T.: Within-canopy sesquiterpene ozonolysis in Amazonia, J. Geophys. Res., 116, D19301, doi:10.1029/2011JD016243, 2011.

Jazukowitsch, H. N.: Mitteilung: A. Kuhlberg aus St. Petersburg. Sitzung der russischen chemischen Gesellschaft vom 1./13. Mai 1875, Ber. deut. chem. Ges., 8, 766-769, 1875.

Jokinen, T., Sipilä, M., Richters, S., Kerminen, V. M., Paasonen, P., Stratmann, F., Worsnop, D., Kulmala, M., Ehn, M., Herrmann, H., and Berndt, T.: Rapid autoxidation forms highly oxidized $\mathrm{RO}_{2}$ radicals in the atmosphere, Angew. Chem., Int. Ed., 53, 14596-14600, 2014.

Kroll, J. H., Clarke, J. S., Donahue, N. M., Anderson, J. G., and Demerjian, K. L.: Mechanism of $\mathrm{HO}_{x}$ formation in the gas-phase ozone-alkene reaction. 1. Direct, pressure-dependent measurements of prompt OH yields, J. Phys. Chem. A, 105, 1554-1560, 2001.

Lathière, J., Hauglustaine, D. A., De Noblet-Ducoudré, N., Krinner, G., and Folberth, G. A.: Past and future changes in biogenic volatile organic compound emissions simulated with a global dynamic vegetation model, Geophys. Res. Lett., 32, L20818, doi:10.1029/2005GL024164, 2005.

Lee, A., Goldstein, A. H., Keywood, M. D., Gao, S., Varutbangkul, V., Bahreini, R., Ng, N. L., Flagan, R. C., and Seinfeld, J. H.: Gas-phase products and secondary aerosol yields from the ozonolysis of ten different terpenes, J. Geophys. Res., 111, D07302, doi:10.1029/2005JD006437, 2006.

Mentel, Th. F., Kleist, E., Andres, S., Dal Maso, M., Hohaus, T., Kiendler-Scharr, A., Rudich, Y., Springer, M., Tillmann, R., Uerlings, R., Wahner, A., and Wildt, J.: Secondary aerosol formation from stress-induced biogenic emissions and possible climate feedbacks, Atmos. Chem. Phys., 13, 8755-8770, doi:10.5194/acp-13-8755-2013, 2013.

Mentel, T. F., Springer, M., Ehn, M., Kleist, E., Pullinen, I., Kurtén, T., Rissanen, M., Wahner, A., and Wildt, J.: Formation of highly oxidized multifunctional compounds: autoxidation of peroxy radicals formed in the ozonolysis of alkenes - deduced from structure-product relationships, Atmos. Chem. Phys., 15, 67456765, doi:10.5194/acp-15-6745-2015, 2015.

Messina, P., Lathière, J., Sindelarova, K., Vuichard, N., Granier, C., Ghattas, J., Cozic, A., and Hauglustaine, D. A.: Global biogenic volatile organic compound emissions in the ORCHIDEE and MEGAN models and sensitivity to key parameters, Atmos. Chem. Phys. Discuss., 15, 33967-34033, doi:10.5194/acpd-1533967-2015, 2015.

Motta, F., Ghigo, G., and Tonachini, G.: Oxidative Degradation of Benzene in the Troposphere. Theoretical Mechanistic Study of the Formation of Unsaturated Dialdehydes and Dialdehyde Epoxides, J. Phys. Chem. A, 106, 4411-4422, 2002.

Neeb, P., Horie, O., and Moortgat, G.: Gas-phase ozonolysis of ethene in the presence of hydroxylic compounds, Int. J. Chem. Kin., 28, 721-730, 1996.

Nguyen, T. L., Winterhalter, R., Moortgat, G., Kanawati, B., Peeters, J., and Vereecken, L.: The gas-phase ozonolysis of $\beta$-caryophyllene $\left(\mathrm{C}_{15} \mathrm{H}_{24}\right)$. Part II: A theoretical study, Phys. Chem. Chem. Phys., 11, 4173-4183, 2009.

Olzmann, M., Kraka, E., Cremer, D., Gutbrod, R., and Andersson, S.: Energetics, kinetics, and product distributions of the reactions of ozone with ethene and 2,3-dimethyl-2-butene, J. Phys. Chem. A, 101, 9421-9429, 1997.

Pan, S. and Wang, L.: Atmospheric oxidation mechanism of mxylene initiated by $\mathrm{OH}$ radical, J. Phys. Chem. A, 118, 1077810787, 2014.

Richters, S., Herrmann, H., and Berndt, T.: Gas-phase rate coefficients of the reaction of ozone with four sesquiterpenes at $295 \pm 2$ K, Phys. Chem. Chem. Phys., 17, 11658-11669, 2015.

Richters, S., Herrmann, H., and Berndt, T.: Highly oxidized $\mathrm{RO}_{2}$ radicals and consecutive products from the ozonolysis of three sesquiterpenes, Environ. Sci. Technol., 50, 2354-2362, 2016.

Rissanen, M. P., Kurtén, T., Sipilä, M., Thornton, J. A., Kangasluoma, J., Sarnela, N., Junninen, H., Jørgensen, S., Schallhart, S., Kajos, M. K., Taipale, R., Springer, M., Mentel, T. F., Ruuskanen, T., Petäjä, T., Worsnop, D. R., Kjaergaard, H. G., and Ehn, M.: The formation of highly oxidized multifunctional products in the ozonolysis of cyclohexene, J. Am. Chem. Soc., 136, 1559615606, 2014.

Rissanen, M. P., Kurtén, T., Sipilä, M., Thornton, J. A., Kausiala, O., Garmash, O., Kjaergaard, H. G., Petäjä, T., Worsnop, D. R., Ehn, M., and Kulmala, M.: Effects of chemical complexity on the autoxidation mechanisms of endocyclic alkene ozonolysis products: from methylcyclohexenes toward understanding $\alpha$-pinene, J. Phys. Chem. A, 119, 4633-4650, 2015.

Scanlon, J. T. and Willis, D. E.: Calculation of flame ionization detector relative response factors using the effective carbon number concept, J. Chromatogr. Sci., 23, 333-340, 1985.

Shu, Y. G. and Atkinson, R.: Rate constants for the gas-phase reactions of $\mathrm{O}_{3}$ with a series of terpenes and $\mathrm{OH}$ radical formation from the $\mathrm{O}_{3}$ reactions with sesquiterpenes at $296 \pm 2 \mathrm{~K}$, Int. J. Chem. Kinet., 26, 1193-1205, 1994. 
Sindelarova, K., Granier, C., Bouarar, I., Guenther, A., Tilmes, S., Stavrakou, T., Müller, J.-F., Kuhn, U., Stefani, P., and Knorr, W.: Global data set of biogenic VOC emissions calculated by the MEGAN model over the last 30 years, Atmos. Chem. Phys., 14, 9317-9341, doi:10.5194/acp-14-9317-2014, 2014.

Suh, I., Zhang, R., Molina, L. T., and Molina, M. J.: Oxidation Mechanism of Aromatic Peroxy and Bicyclic Radicals from $\mathrm{OH}-$ Toluene Reactions, J. Am. Chem. Soc., 125, 12655-12665, 2003.

Vereecken, L. and Francisco, J. S.: Theoretical studies of atmospheric reaction mechanisms in the troposphere, Chem. Soc. Rev., 41, 6259-6293, 2012.

Vereecken, L. and Peeters, J.: Nontraditional (per)oxy ring-closure paths in the atmospheric oxidation of isoprene and monoterpenes, J. Phys. Chem. A, 108, 5197-5204, 2004.

Vereecken, L. and Peeters, J.: A theoretical study of the $\mathrm{OH}-$ initiated gas-phase oxidation mechanism of $\beta$-pinene $\left(\mathrm{C}_{10} \mathrm{H}_{16}\right)$ : first generation products, Phys. Chem. Chem. Phys., 14, 38023815, 2012.

Vereecken, L., Müller, J. F., and Peeters, J.: Low-volatility polyoxygenates in the $\mathrm{OH}$-initiated atmospheric oxidation of $\alpha$ pinene: impact of non-traditional peroxyl radical chemistry, Phys. Chem. Chem. Phys., 9, 5241-5248, 2007.

Vereecken, L., Harder, H., and Novelli, A.: The reaction of Criegee intermediates with $\mathrm{NO}, \mathrm{RO}_{2}$, and $\mathrm{SO}_{2}$, and their fate in the atmosphere, Phys. Chem. Chem. Phys., 14, 14682-14695, 2012.
Welz, O., Eskola, A. J., Sheps, L., Rotavera, B., Savee, J. D., Scheer, A. M., Osborn, D. L., Lowe, D., Murray Booth, A., Xiao, P., Anwar, H. K. M., Percival, C. J., Shallcross, D. E., and Taatjes, C. A.: Rate coefficients of $\mathrm{C} 1$ and $\mathrm{C} 2$ Criegee intermediate reactions with formic and acetic acid near the collision limit: direct kinetics measurements and atmospheric implications, Angew. Chem. Int. Ed., 53, 4547-4550, 2014.

Winterhalter, R., Herrmann, F., Kanawati, B., Nguyen, T. L., Peeters, J., Vereecken, L., and Moortgat, G. K.: The gas-phase ozonolysis of $\beta$-caryophyllene $\left(\mathrm{C}_{15} \mathrm{H}_{24}\right)$. Part $\mathrm{I}$ : an experimental study, Phys. Chem. Chem. Phys., 11, 4152-4172, 2009.

Yu, J. and Jeffries, H. E.: Atmospheric photooxidation of alkylbenzes-II. Evidence of formation of epoxide intermediates, Atmos. Environ., 31, 2281-2287, 1997.

Zhao, Y., Wingen, L. M., Perraud, V., and Finlayson-Pitts, B. J.: Phase, composition, and growth mechanism for secondary organic aerosol from the ozonolysis of $\alpha$-cedrene, Atmos. Chem. Phys., 16, 3245-3264, doi:10.5194/acp-16-3245-2016, 2016.

Ziemann, P. J. and Atkinson, R.: Kinetics, products, and mechanisms of secondary organic aerosol formation, Chem. Soc. Rev., 41, 6582-6605, 2012. 